\title{
Citizen science can improve conservation science, natural resource management, and environmental protection
}

\author{
Duncan C. McKinley ${ }^{\mathrm{a}, *}$, Abe J. Miller-Rushing ${ }^{\mathrm{b}}$, Heidi L. Ballard ${ }^{\mathrm{c}}$, Rick Bonney ${ }^{\mathrm{d}}$, Hutch Brown ${ }^{\mathrm{a}}$, \\ Susan C. Cook-Patton ${ }^{\text {e, Daniel M. Evans }}{ }^{\mathrm{e}}$, Rebecca A. French ${ }^{\mathrm{f}}$, Julia K. Parrish ${ }^{\mathrm{g}}$, Tina B. Phillips ${ }^{\mathrm{d}}$, Sean F. Ryan ${ }^{\mathrm{h}}$,
} Lea A. Shanley ${ }^{\mathrm{i}}$, Jennifer L. Shirk ${ }^{\mathrm{d}}$, Kristine F. Stepenuck ${ }^{\mathrm{j}}$, Jake F. Weltzin ${ }^{\mathrm{k}}$, Andrea Wiggins ${ }^{1}$, Owen D. Boyle ${ }^{\mathrm{m}}$, Russell D. Briggs $^{\mathrm{n}}$, Stuart F. Chapin III ${ }^{ }$, David A. Hewitt ${ }^{\mathrm{p}}$, Peter W. Preuss ${ }^{\mathrm{q}}$, Michael A. Soukup ${ }^{\mathrm{r}}$

a USDA Forest Service, United States

${ }^{\mathrm{b}}$ National Park Service, Schoodic Education and Research Center at Acadia National Park, United States

c University of California Davis, United States

d Cornell Lab of Ornithology, United States

e AAAS Science \& Technology Policy Fellow at the USDA Forest Service, United States

${ }^{\mathrm{f}}$ AAAS Science E Technology Policy Fellow at the EPA, United States

$\mathrm{g}$ University of Washington, United States

${ }^{\mathrm{h}}$ University of Notre Dame, United States

i University of Wisconsin Madison and South Big Data Hub at University of North Carolina-Chapel Hill, United States

${ }^{\mathrm{j}}$ University of Wisconsin Extension at the University of Wisconsin, United States

${ }^{k}$ U.S. Geological Survey, United States

${ }^{1}$ University of Maryland College Park, United States

m Wisconsin Department of Natural Resources, United States

${ }^{\mathrm{n}}$ State University of New York, United States

o University of Alaska Fairbanks, United States

p Academy of Natural Sciences and Evidential Planning and Management, LLC, United States

q U.S. Environmental Protection Agency, United States

${ }^{\mathrm{r}}$ Schoodic Institute at Acadia National Park, United States

\section{A R T I C L E I N F O}

\section{Article history:}

Received 13 October 2015

Received in revised form 14 April 2016

Accepted 23 May 2016

Available online 21 June 2016

\section{Keywords:}

Citizen science

Public participation in scientific research

Conservation

Policymaking

Natural resource management

Public input

Public engagement

\section{A B S T R A C T}

Citizen science has advanced science for hundreds of years, contributed to many peer-reviewed articles, and informed land management decisions and policies across the United States. Over the last 10 years, citizen science has grown immensely in the United States and many other countries. Here, we show how citizen science is a powerful tool for tackling many of the challenges faced in the field of conservation biology. We describe the two interwoven paths by which citizen science can improve conservation efforts, natural resource management, and environmental protection. The first path includes building scientific knowledge, while the other path involves informing policy and encouraging public action. We explore how citizen science is currently used and describe the investments needed to create a citizen science program. We find that:

1. Citizen science already contributes substantially to many domains of science, including conservation, natural resource, and environmental science. Citizen science informs natural resource management, environmental protection, and policymaking and fosters public input and engagement.

2. Many types of projects can benefit from citizen science, but one must be careful to match the needs for science and public involvement with the right type of citizen science project and the right method of public participation.

3. Citizen science is a rigorous process of scientific discovery, indistinguishable from conventional science apart from the participation of volunteers. When properly designed, carried out, and evaluated, citizen science can provide sound science, efficiently generate high-quality data, and help solve problems.

\footnotetext{
* Corresponding author.

E-mail address: dcmckinley@fs.fed.us (D.C. McKinley).
} 


\section{Introduction}

The enormous scale and complexity of current environmental problems pose serious challenges for the fields of conservation biology, natural resource management, and environmental protection. Citizen science offers a powerful tool for tackling these challenges.

The challenges are immense. The biological and physical systems of our planet are undergoing rapid rates of change as the impact of human activities becomes nearly ubiquitous (Pimm and Raven, 2000; Steffen et al., 2011). Stressors like urbanization, deforestation, land conversion to agriculture, and climate change strain the capacity of natural systems to sustain life and threaten the persistence of many species (Dirzo et al., 2014; McCauley et al., 2015; Pimm and Raven, 2000; Steffen et al., 2011). Extinction rates might be as high as 100 to 1000 times greater than pre-human levels (Pimm et al., 1995), and these bleak estimates may be too low if unidentified species disappear before they are discovered (Scheffers et al., 2012).

Yet cataloguing even a fraction of the unknown diversity is ambitious (Carbayo and Marques, 2011). Conservation strategies require knowledge of species distributions, but even well-known species can have poorly resolved geographic ranges (Jetz et al., 2012) that can shift in response to climate change (Chen et al., 2011). Moreover, successful conservation efforts must focus on more than ecological dynamics and address the social, cultural, and political factors that affect natural ecosystems (e.g., Balmford and Cowling, 2006; Mascia et al., 2003). To be effective, conservation efforts must also incorporate public input and engagement in crafting solutions (Eden, 1996; Germain et al., 2001; Steelman, 2001).

We describe here how citizen science can improve conservation outcomes by building scientific knowledge, informing policy formulation, and inspiring public action. We focus on the United States, but many of our findings are relevant to other countries with similar systems of governance. We start by describing citizen science and discussing how it can help to address major conservation challenges. We then describe the value and limitations of citizen science for meeting core scientific needs, as well as the value and limitations of citizens for promoting public input and engagement in conservation. We end by discussing the investments that citizen science requires.

Our goal is to help people involved in conservation science and decisionmaking, natural resource management, and environmental protection (1) decide whether citizen science will help them meet their science and/or public input and engagement needs, and (2) make informed decisions about investing in citizen science. We aim to provide a balanced assessment of whether, when, and how to employ citizen science to help meet information and public engagement needs.

\section{Methods}

We assembled a team of citizen science experts and practitioners from multiple federal and state agencies, universities, and nongovernmental organizations. Individuals on the team have many years of experience designing, managing, and evaluating citizen science projects from across the United States. We also represent many different perspectives and take different approaches to studying and using citizen science in research, education, and management applications.

Our team of coauthors was challenged to answer the question, can citizen science improve conservation science, natural resource management, and environmental protection? We gathered at two intensive workshops in June and September 2013 where we mapped out the conceptual framework for answering the question and identified the most essential papers to reference. We also worked extensively outside of the workshops to review the literature and consult with other experts and practitioners. We used Web of Science to identify additional references to better substantiate some of the points raised at the workshop and to frame the paper in a broader context. Given the multi- disciplinary nature of the subject matter in a variety of contexts, requiring many search terms, we can cite only the most pertinent references and examples. This review represents the authors' consensus view of the state of the field that emerged from those workshops.

\section{Results and discussion}

\subsection{What is citizen science?}

Citizen science means different things to different people, causing confusion about its nature and utility. We define the term as the practice of engaging the public in a scientific project-a project that produces reliable data and information usable by scientists, decisionmakers, or the public and that is open to the same system of peer review that applies to conventional science. The public can also contribute to science through crowdsourcing, a practice that typically involves large numbers of people processing and analyzing data, but in this paper we focus on public involvement in data collection. Apart from the participation of volunteers, citizen science, as we define it, is indistinguishable from conventional science led by paid scientists at academic, government, non-profit, or commercial organizations and carried out by a mix of professional scientists and paid technicians or students. Both citizen science and conventional science use a variety of methods to achieve a variety of goals, including basic research, management, and education. Citizen science is science (with the addition of volunteers) and should be treated as such in its design, implementation, and evaluation.

Citizen science is not new. Before science first emerged as a profession, keen amateurs and volunteers conducted scientific research and made key contributions to the understanding of climate, evolution, geology, electricity, astronomy, and other phenomena (Miller-Rushing et al., 2012; Silvertown, 2009). Their work continues to provide valuable information. Henry David Thoreau's painstaking records from the $1850 \mathrm{~s}$ of the first flowers, leaves, and bird arrivals each spring are now used by scientists to identify the impacts of climate change (Ellwood et al., 2010; Polgar et al., 2014; Primack and Miller-Rushing, 2012). In the 1930s and 1940s, Aldo Leopold noted a range of discoveries made by contemporary citizen science volunteers and concluded that "the sport-value of amateur research is just beginning to be realized." In fact, citizen science volunteers continue many of Leopold's research projects today (Ellwood et al., 2013).

Citizen science projects can pursue basic or applied science. They can monitor ecological or environmental baselines, respond to crises, and inform management actions (Hemmi and Graham, 2014; McCormick, 2012; Nichols and Williams, 2006; Sullivan et al., 2009). Citizen science can tackle issues at local scales, such as identifying the source of pollution in a single stream (Danielsen et al., 2010; Middleton, 2001); it can also address issues at regional or global scales, such as climate change or the world's great animal migrations (Fuccillo et al., 2015; Sullivan et al., 2009).

Volunteers can participate in a little or a lot of the scientific process. For instance, they might formulate a scientific question and then contract with professional scientists to conduct the research; or they might collaborate closely with professional scientists to jointly develop a project, collect and analyze data, and report the results (Shirk et al., 2012). Members of the public, alone or in groups, may even pursue scientific research wholly on their own and fill needs unmet by professionals (Shirk et al., 2012 (collegial model); Middleton, 2001). However, volunteers usually contribute by collecting data in projects designed by professional scientists.

The information technology revolution and the advent of the Internet and location-aware mobile technologies equipped with cameras and other sensors (Hart and Martinez, 2006; Zerger et al., 2010) have greatly increased the capacity of what citizen scientists can do, leading to the rising use of citizen science data in peer-reviewed publications (Ries and Oberhauser, 2015). People can now access, store, manage, analyze, and share vast amounts of data and communicate information 
quickly and easily (Poelen et al., 2014). Powered by public interest and increased technological capacity, today's citizen scientist can help answer the most challenging ecological and environmental questions of our day (Hemmi and Graham, 2014; McCormick, 2012).

\subsection{How can citizen science help to address major conservation challenges?}

Citizen science can help to address major conservation challenges by (1) enabling science that might not otherwise be feasible because of scale or for other practical reasons, and (2) better engaging the public in helping to make decisions. There are thus two ways for citizen science to improve conservation policies and outcomes (Fig. 1). One pathway involves acquiring scientific knowledge, just like conventional research. Volunteers help generate scientific information for conservation scientists, natural resource and environmental managers, and other decisionmakers. The other pathway stimulates public input and engagement in natural resource and environmental management and policymaking. Volunteers can directly provide input into decisions-for example, by using what they learned in a citizen science project to comment on a proposed government action. Their input and engagement can also be indirect-for example, they might share information within their communities and motivate others to get involved in conservation, natural resource and environmental management, and policy discussions and decisions.

We separate the pathways in this paper for ease of explanation, but in practice the pathways converge and can be mutually reinforcing, generating synergies between science and public input and engagement (Fig. 1). Most citizen science projects involve both pathways (often at the same time), but projects can vary, and the design of a project influences the type of scientific information it provides and the quality and method of public engagement it facilitates (Shirk et al., 2012; Gray et al., 2016). Scientists and land managers must therefore carefully choose citizen science project designs to meet their needs and goals.

Together, the two pathways can contribute at various points in a typical policy cycle (Fig. 1). Citizen science can make valuable systematic observations and identify problems or issues; help in formulating public

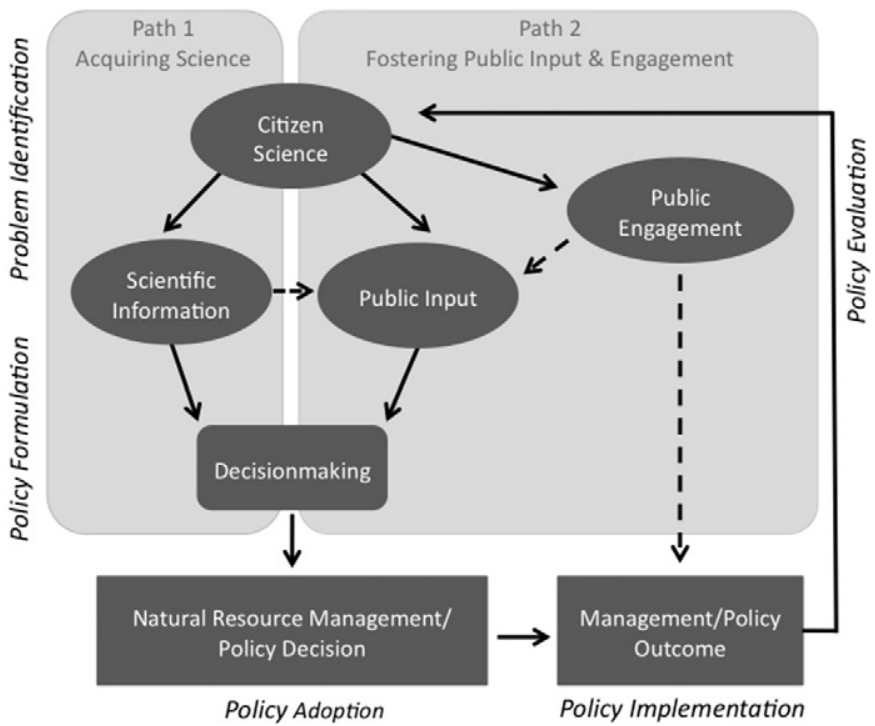

Fig. 1. The two pathways that citizen science can take to inform conservation, natural resource management, and environmental protection by acquiring scientific information and fostering direct (solid arrows) and indirect (dashed arrows) public input and engagement. Note that these two paths are not distinct but converge and can be mutually reinforcing, generating synergies between science and public input and engagement. The italicized text around the edge refers to the policy cycle: issue or problem identification produces a need; policy formulation addresses the issue; policy adoption points to a way of resolving the issue; policy implementation entails taking action; and policy evaluation assesses policy effectiveness and outcomes, initiating the next policy cycle. policy; strengthen public input into policymaking; help government agencies and other organizations implement policies; help evaluate the impact of a policy or decision; and help in enforcing laws and regulations pertaining to conservation, natural resources, and the environment (Couvet et al., 2008; Eden, 1996).

\subsection{Can citizen science meet core science needs?}

To make decisions about how to manage species and landscapes, organizations rely on the "best available science." The best science does not necessarily come from the best peer-reviewed scientific publications with the most robust designs and inferences; rather, it is the best scientific information available to answer a specific question (Hemmi and Graham, 2014; Sullivan et al., 2006).

Citizen science can help meet diverse informational needs and achieve management outcomes (Table 1 ), and steps can be taken to ensure data integrity. For example, citizen scientists can engage in monitoring studies. They can track patterns, in space and/or time, of one or more ecosystem components. They can answer questions like, is this species here now? Or how many individuals of this species are here? Citizen science can also monitor ecosystem functions and answer, for example, is this process happening now? Data integrity is achieved through standardized sampling procedures that are the same for all sampling locations and effort-controlled so that zeros are recorded even if nothing is found (Conrad and Hilchey, 2011; Danielsen et al., 2005a; Sullivan et al., 2009).

Citizen scientists can engage in process studies and assess the impacts of factors on ecosystem components or functions. They can, for example, look at how pollution affects water quality. For these experiments, researchers control the level and duration of the exposure, and there is a control treatment (which might be the status quo) (Wiersma, 2010).

Citizen scientists can also help with opportunistic and observational studies that do not follow a strict design but are often deliberate in the subject and timing of observation. These studies can be useful because of the large temporal or geographic scale of the data collection, the rarity of the phenomena observed (e.g., a rare species or infrequent weather event), or the timeliness of the observations (e.g., collecting information for crisis response, such as after earthquakes or oil spills), all of which make data collection difficult (Allen, 2012; Dickinson et al., 2012; Dickinson et al., 2010; Losey et al., 2007; McCormick, 2012).

\subsubsection{What scientific value does citizen science add?}

There are multiple ways that citizen science can provide advantages over conventional science. It can often operate at greater geographic scales and over longer periods of time than conventional science-and sometimes at greater resolutions. Only volunteers can cost-effectively collect some types of data, such as observations of breeding birds and other physical and biological phenomena, in sufficiently large areas and over long enough periods of time to be scientifically reliable and meaningful (Bhattacharjee, 2005; Devictor et al., 2010; Zapponi et al., 2016; Edgar et al., 2016). The North American Breeding Bird Survey, for example, has relied on volunteers to track the abundance of bird populations across the continent (Case Study 1) (Rodriguez, 2002; Sauer et al., 2003). Other projects, such as Nature's Notebook, encourage volunteers and professional scientists to regularly submit observations of plant and animal occurrences, behaviors, and seasonal events such as tree leafout and the timing of animal breeding (Fuccillo et al., 2015). In some cases, projects have benefited greatly from volunteers collecting data when scientists are not typically present, such as during the Arctic autumn and winter (Solli et al., 2013). Organizations use online applications such as IveGot1 and Bugwood to track the presence or absence of invasive species, to better understand how invasive species spread, and to collect other vital information (Wallace and Bargeron, 2014). In addition, hundreds of air and water quality monitoring programs across the country depend largely on data and samples collected 
Table 1

Examples of citizen science projects/programs used to meet needs for science and public input/engagement common to many natural resource and environmental organizations.

\begin{tabular}{|c|c|c|c|}
\hline Management goal & Science needs & Public input and engagement needs & Sample projects \\
\hline Species management & $\begin{array}{l}\text { Providing information on species abundance, } \\
\text { distribution, phenology, and behavior }\end{array}$ & $\begin{array}{l}\text { Public support for and involvement in management } \\
\text { decisions }\end{array}$ & $\begin{array}{l}\text { North American Breeding Bird Survey; } \\
\text { Monarch Watch; eBird; Grunion Greeters; } \\
\text { IceWatch USA }\end{array}$ \\
\hline $\begin{array}{l}\text { Ecosystem services } \\
\text { management }\end{array}$ & $\begin{array}{l}\text { Providing resource valuation; mapping } \\
\text { ecosystem services }\end{array}$ & Public appreciation for ecosystem services & $\begin{array}{l}\text { USGS's Social Values for Ecosystem Services } \\
\text { (SoLVES) }\end{array}$ \\
\hline $\begin{array}{l}\text { Climate change, } \\
\text { impact assessment, } \\
\text { adaptation }\end{array}$ & $\begin{array}{l}\text { Assessing the status, rates, and trends of key } \\
\text { physical, ecological, and societal variables } \\
\text { and values }\end{array}$ & $\begin{array}{l}\text { Stakeholder engagement in program development, } \\
\text { implementation, and evaluation }\end{array}$ & $\begin{array}{l}\text { Nature's Notebook; Community } \\
\text { Collaborative Rain, Hail and Snow Network }\end{array}$ \\
\hline $\begin{array}{l}\text { Invasive species } \\
\text { control }\end{array}$ & $\begin{array}{l}\text { Providing real-time monitoring (an } \\
\text { early-alert system) }\end{array}$ & $\begin{array}{l}\text { Public support for and involvement in management } \\
\text { decisions }\end{array}$ & IveGot1 app; Bugwood app \\
\hline $\begin{array}{l}\text { Pollution detection } \\
\text { and enforcement }\end{array}$ & $\begin{array}{l}\text { Providing information on water and air } \\
\text { quality }\end{array}$ & $\begin{array}{l}\text { Stakeholder engagement in identifying problems and } \\
\text { solutions; public support for and involvement in } \\
\text { management decisions }\end{array}$ & $\begin{array}{l}\text { Bucket Brigade; Clean Air Coalition; } \\
\text { Alabama Water Watch Program }\end{array}$ \\
\hline
\end{tabular}

by citizen science volunteers (Case Study 2) (Stepenuck and Green, 2015). The resulting observations are used by professional scientists, government agencies, non-governmental organizations, and other decisionmakers (Stepenuck and Green, 2015).

Citizen science can speed up and improve field detection (Liebenberg et al., 2016). Having many eyes on the ground can help detect environmental changes (e.g., detecting changes in the onset of spring through plant phenology (Fuccillo et al., 2015)); identify phenomena that require management responses (e.g., population declines, incidences of pollution, and introduction of an invasive species (Hemmi and Graham, 2014; Ingwell and Preisser, 2011; McCormick, 2012; Barnard et al., 2016)); monitor the effectiveness of management practices (Conrad and Hilchey, 2011); and increase the likelihood of a serendipitous discovery. For example, the lead author discovered a new species of cricket while participating in a citizen science project aimed at learning more about the range and distribution of a similar but well-known species. Volunteers have filled data gaps and detected unusual occurrences that might have eluded conventional science and monitoring. For example, the Cornell Lab of Ornithology's FeederWatch program was able to track rapidly spreading disease in house finches and other birds across 33 states based on information that volunteers collected at bird feeders (Altizer et al., 2004; Dhondt et al., 1998). Citizen science data combined with laboratory studies gave critical new insights into how to slow or prevent future epidemics among wildlife and humans (Crowl et al., 2008; Meentemeyer et al., 2015).

Citizen science can improve data and image analysis. People are able to recognize patterns and interpret large amounts of data as well as to distinguish subtle differences among characteristics. Volunteers with no specialized training (such as high school students) have performed as well as or better than highly trained scientists and state-of-the-art algorithms in certain analytical tasks, for example in "protein folding" to help scientists better understand proteins through the Foldit computer game (Cooper et al., 2010; Khatib et al., 2011). Volunteers with proper training and guidance can accurately identify specimens at various taxonomic levels and accurately assess important population attributes, such as species abundance and distribution (Crall et al., 2011; Danielsen et al., 2014). Volunteers can also extract information from digitally collected primary data (such as images or audio) by identifying and recording secondary information (e.g., species identity; the presence or absence of a species; and the abundance, behavior, and frequency or duration of various phenomena), tasks that are often difficult for computers (Ellwood et al., 2015). In some cases, highly trained volunteers such as retired professionals might be able to contribute to higher level data analysis.

Citizen science can help refine research questions. Participants in citizen science are affected by and observe local natural resources and the environment in their daily lives, so they can help improve the relevancy of location-specific research questions and make them more useful to managers and local communities (Ballard et al., 2008; McKinley et al., 2012). For example, people in Washington state harvest salal, a culturally and economically important forest shrub used in floral arrangements and also important for wildlife habitat (Ballard and Huntsinger, 2006). Concerned about the decline of salal, scientists worked with people who harvest the shrub to formulate research questions about sustainable use of the plant. The results helped everyone involved understand why salal might decline and how to harvest it without diminishing the resource. Volunteers can also use local or traditional knowledge to help professional scientists interpret results, particularly in explaining unusual data and in research projects that explore how people interact with ecological processes (Ballard and Huntsinger, 2006; Haberl et al., 2006; Huntington, 2000; Laidler, 2006). A full understanding of natural resource and environmental issues often requires a holistic perspective, including human dimensions; citizen science can help provide this perspective and improve research.

Citizen science can help researchers better identify and study connections between humans and their environment. Citizen science is well suited for interdisciplinary collaboration, particularly for projects that include both natural and social dimensions. Conservation scientists and natural resource and environmental managers increasingly address the social aspects of difficult ecological issues, such as managing wildfires in the wildland-urban interface and conserving nature in humandominated landscapes (Cooper et al., 2007; McKinley et al., 2012; Winter et al., 2002). By engaging local community members, citizen science can facilitate an understanding among managers, scientists, regulators, decisionmakers, volunteers, and others of the social dimensions of the natural systems where people live (Cooper et al., 2007; McKinley et al., 2012).

\subsubsection{What are the limitations of citizen science for achieving science goals?}

Many scientific projects are not appropriate for citizen science. The most common factor limiting volunteer participation in a scientific project is the ability of trained volunteers to meaningfully contribute to the science (Powell and Colin, 2008). Questions, methods, and analyses sometimes require specialized knowledge, training, equipment, and time commitments that make citizen science inefficient or impractical as an approach (Snall et al., 2011; McDonough-MacKenzie et al., 2016). Volunteers should not be expected to use sophisticated analytical instruments or participate in activities that require extensive training or certification. Generally speaking, the simpler the methods, the easier it is to engage volunteers in the collection of high-quality data; simple tasks also make it feasible to increase the number of contributors and easier to sustain collection of high-quality data (Parsons et al., 2011).

Additionally, not all citizen science projects stimulate widespread public interest, whether driven by curiosity or concern. Because interests vary, people are selective about participating in citizen science. For example, charismatic species such as wolves, bears, and certain birds receive more public attention (and support for public funding) than do other species, including most plants (Clark et al., 2002). Similarly, places easier or more convenient to access, such as water bodies near 
tourist destinations and college campuses, tend to receive the most attention (Betts et al., 2007; van Strien et al., 2013). In addition, studies in small or remote communities might be of great local interest, yet the pool of potential participants in a citizen science project might be small. For certain taxa and ecological processes and for some biogeographic regions or geographic locations, it is difficult to sustainably do many types of citizen science projects.

For field work, potentially hazardous conditions or the need for frequent sampling can limit the feasibility of citizen science. Few volunteers are able to devote extended periods of time to scientific projects. Extremely frequent (e.g., daily) sampling needs therefore might discourage participation and increase turnover. There can also be a mismatch between the availability of volunteers and the availability of managers or their staffs; for example, participants might be available primarily on weekends, when staff is unavailable. As a result, it might be difficult to recruit citizen science volunteers for certain projects.

At the other extreme, infrequent (e.g., annual) sampling might make it harder to sustain collection of high-quality data, because participants might have to relearn even basic protocols. A successful sampling design for volunteers lies in between, where sampling frequency is just enough to keep participants well practiced and able to gather consistent data but not so high as to become onerous and discourage participation (Theobald et al., 2015).

Finally, citizen science projects that simultaneously engage volunteers in scientific research and in policy processes may be perceived as introducing biases into decisionmaking. But this is not a problem unique to citizen scientists; professional scientists must also guard against bias, especially those who are involved in both conducting research and informing decisionmakers (Eden, 1996; Haller and Gerrie, 2007; Yamamoto, 2012). Ensuring data relevance, credibility, and accuracy of the scientific information is one way to avoid biases (Yamamoto, 2012). Similar quality controls can be used for both citizen science and conventional science; they can include training, collection of duplicate samples, and post-data collection analyses designed to identify outliers and biases in the data (Boudreau and Yan, 2004; Crall et al., 2011; Darwall and Dulvy, 1996; Gardiner et al., 2012). Moreover, citizen scientists and professional scientists can produce data that are of equally high quality (Edgar and Stuart-Smith, 2009). Thus, while establishing quality controls for citizen scientists is important, quality controls are also a standard scientific practice, and there is nothing particularly special about quality controls in citizen science that conventional science does not already have the tools to handle.

\subsection{How can citizen science promote public input and engagement?}

For federal, state, and municipal agencies as well as many nongovernmental organizations, public input and engagement are essential in formulating and achieving goals for conservation, natural resource management, and environmental protection (Chess and Purcell, 1999; Dietz and Stern, 2008; McKinley et al., 2012; Predmore et al., 2011; Rowe and Frewer, 2005; Wesselink et al., 2011). Federal law requires federal agencies to disclose the impacts of their major activities and to solicit public input or participation at important stages in the process of land management and policy development (Predmore et al., 2011). We define "public input" as feedback from the public in response to a call from government or other organizations for input. Examples include public comment periods following the release of environmental impact statements and meetings of advisory committees, such as those set up under the Federal Advisory Committee Act (Long and B.T.C., 1999; Steelman, 1999). We define "public engagement" as officials, specialists, and other employees interacting with the public to exchange ideas about a problem or a proposed solution or other management action or goal (Fernandez-Gimenez et al., 2008). This is typically done through education programs, public outreach, and town hall meetings. Public participation was originally intended to prevent special interest groups from unduly influencing federal decisionmaking.
Now, public input and engagement are increasingly viewed as essential in crafting sustainable and locally appropriate management activities and policies (Holmes and Clark, 2008; Sultana and Abeyasekera, 2008; Thompson et al., 2005; Wesselink et al., 2011) (Case Study 3).

Citizen science projects can enhance a bidirectional flow of information between the public, conservation scientists, natural resource managers, and environmental policy organizations (Fortmann and Ballard, 2011; Groffman et al., 2010; Lawrence, 2006; McKinley et al., 2012; Robertson and Hull, 2003; Shirk et al., 2012; Sunderland et al., 2009; Wals et al., 2014). Volunteers, through the training they receive for a citizen science project, can come to better understand the ability (or inability) of science to answer a question of interest (Trumbull et al., 2000). They can also learn from a project's science outcomes, particularly if the project advances knowledge or sheds light on an issue of concern (Zerbe and Wilderman, 2010). In turn, conservation scientists, natural resource managers, and environmental organizations receive input from volunteers, providing them with a better understanding of public priorities and social contexts and thereby contributing to a richer, more productive public dialogue (Cooper et al., 2007; Kapoor, 2001; Stepenuck and Green, 2015).

\subsubsection{What value does citizen science add to public input and engagement?}

Under the right circumstances, citizen science projects can have many benefits. They can engage people in decisionmaking processes by increasing firsthand understanding of conservation or environmental issues and encouraging participants to become more responsive to the issues they care about (Zerbe and Wilderman, 2010). Participants might become more likely to appear at public meetings and to provide constructive comment on proposed actions (Overdevest et al., 2004). For example, members of Golden Gate Audubon participate in bird monitoring and invasive species removal projects and present their findings to local agencies. They also recognize that science is important for achieving other local conservation goals and form committees to recommend and implement additional citizen science projects (California Academy of Sciences, 2012).

Citizen science can promote collaboration, creating synergies and improving outcomes (Armitage et al., 2009; Danielsen et al., 2005b; Kapoor, 2001; Selin et al., 2007; Shirk et al., 2012). Some federal agencies engage the public in multiparty monitoring, a collaborative form of citizen science in which people with diverse interests work together to understand a problem, conduct monitoring, and evaluate project results (Derr et al., 2005). Multiparty monitoring often enlists volunteers. For example, the Uncompahgre Plateau Project in western Colorado, part of the Forest Service's Collaborative Forest Landscape Restoration Program, specifically calls for citizen science volunteers in its monitoring strategy (Case Study 4) (Schultz et al., 2012).

Citizen science can bring fresh perspectives and critical information into decisionmaking. The participatory nature of citizen science can facilitate the inclusion of diverse perspectives in decisionmaking (Danielsen et al., 2007; Dietz and Stern, 2008; Kapoor, 2001; Selin et al., 2007). Volunteers might represent a different constituency than participants in other types of public engagement. Fuller public representation can better ensure that outcomes meet the needs of more people (Brussard et al., 1998; Dietz and Stern, 2008; Shanley and Lopez, 2009). Citizen science can also provide the critical information that decisionmakers need to act; in some cases, it can also shorten the time from data collection to decisionmaking. For example, the Coastal Observation and Seabird Survey Team (COASST) collects information on beached birds on almost 450 beaches in northern California, Oregon, Washington, and Alaska. Thanks in part to the program's extensive network of about 850 volunteers, its robust protocol, and its sound reputation, COASST has provided near-real-time information to decisionmakers on the impacts of such events as harmful algal blooms and fishery bycatch on coastal seabirds, even as an event unfolds (Litle et al., 2006). 
Citizen science can foster environmental stewardship, because collecting environmental data can prompt volunteers to care more about the environment and develop a sense of place (Evans et al., 2005; Ballard et al., 2016). When citizen scientists engage in research around local conservation issues, it can deepen the relationship between them and the environment in which they live. The resulting sense of place can in turn inspire increased engagement in decision making and help link citizen science efforts to local needs (Newman et al., 2016). After participating in citizen science, people might also make different personal choices, changing their own management practices (Brossard et al., 2005; Cooper et al., 2007; Danielsen et al., 2005b; Danielsen et al., 2007; Johnson et al., 2014; Jordan et al., 2011; Stepenuck and Green, 2015). Volunteers for Monarch Watch, for example, helped to tag individual monarch butterflies to help scientists study monarch populations and migrations (http://monarchwatch.org/). After learning how habitat for monarchs is vanishing, many volunteers have planted pollinator gardens in their own backyards.

Citizen scientists can spread knowledge among their friends, family, and colleagues by sharing their citizen science activities and discussing the issues they care about through a wide range of social networks (Yaffee and Wondolleck, 1995; Nerbonne and Nelson, 2004; Overdevest et al., 2004; Johnson et al., 2014; Forrester et al., 2016). The information they impart and the example they set can motivate others to get involved or to change their own behavior (Stepenuck and Green, 2015). People are more likely to change their behavior in response to examples set by their friends and neighbors than in response to public information campaigns (Bikhchandani et al., 1992).

Citizen science can answer local community questions of concern that are important for local management and policy but might go unaddressed by professional science (Arlettaz et al., 2010; McNie, 2007; Raymond et al., 2010; Vogel et al., 2007). Such questions might be too scientifically novel or not novel enough; they might not be a priority for funding by federal or state agencies; and local organizations might not have enough scientific capacity to address them (Walker, 2002). As a result, many citizen science projects have sprung from local community concerns impossible to address in any other way (e.g., Middleton, 2001). In one study in Tonawanda, NY, for example, community members undertook an air quality investigation in their heavily industrialized town, leading to law enforcement actions (Case Study 5) (https://www.cacwny.org/campaigns/tonawanda/). In such cases, the public contributes local perspectives that professional scientists might otherwise miss. Involving local volunteers in a project can bring out questions, ideas, and techniques that might not otherwise surface, with professional scientists furnishing support, training, and advice. The Environmental Protection Agency office that serves the people of New York State has launched a website (http://www.epa. gov/citizenscience/) providing resources for citizen science, including data collection guidelines, case studies, and information about funding.

Citizen science can use local and traditional knowledge to interpret research results, set science and management priorities, and craft management activities (Ballard et al., 2008; Cornwall and Jewkes, 1995; Huntington, 2000; McLain et al., 1998; Raymond et al., 2010; Liebenberg et al., 2016). For example, the Wallowa-Whitman National Forest in Oregon worked with the non-governmental organization Wallowa Resources to include ranchers and others in a collaborative watershed assessment (a version of multi-party monitoring). The partners monitored how livestock interacted with water resources in the national forest and contributed information about the history of grazing practices across the forest. Forest Service managers used the information to decide on management actions to relieve livestock pressure around lakes and rivers while improving animal production and distribution, a measure supported by local ranchers (Wallowa County Community Planning Process Group, 2005).

Citizen science can improve science literacy and build expertise by helping volunteers better access and understand scientific information (Bonney et al., 2009; Dietz and Stern, 2008; Evans et al., 2005; Jordan et al., 2013; Price and Lee, 2013; Yamamoto, 2012; Chandler et al., 2016). Well-designed citizen science projects can even steer volunteers toward science- or management-related careers (Johnson et al., 2014). Professional scientists are finding that some citizen science volunteers, particularly young adults, show enthusiasm and aptitude for scientific research. Citizen science can increase and diversify the pool of candidates available for jobs in conservation science, natural resource management, and environmental protection.

\subsubsection{What are the limitations of citizen science for public input and engagement?}

Citizen science is only one of many ways of engaging the public in decisionmaking processes and environmental stewardship, and it is not always the best way. Sometimes direct public outreach is more effective than citizen science projects are (Lane et al., 2007), particularly when the connection between the science and management or policy decisions is weak or not obvious. If scientific knowledge is already adequate, for example, then citizen science is not needed-the knowledge can be communicated and input and engagement sought through conventional means such as newsletters, science cafés, or public meetings.

Moreover, designing a citizen science project that will change behavior is difficult, and evidence for actual change in behavior is limited (Crall et al., 2013), though some examples do exist (Funder et al., 2013; Lewandowski, 2016). Successful projects are usually designed to encourage particular behaviors, whether planting butterfly gardens or attending public meetings. The goals must be reasonable-for example, encouraging gardeners to switch to native or wildlife-friendly plants is likely easier to achieve than getting non-gardeners to plant native gardens. Achieving goals for public input and engagement requires planning and expertise, and many citizen science projects do not have the resources to reach such goals. This is an active area of research, and more work is needed.

\subsection{Synergy between science acquisition and public input and engagement pathways}

Citizen science is most valuable for conservation science, natural resource management, and environmental protection when it generates science and increases substantive public input and engagement (Aceves-Bueno et al., 2015). Few people have the opportunity to engage in scientific research, and most never participate in natural resource management and environmental decisionmaking. Through citizen science, participants can learn how science is done and how it contributes to conservation, natural resource management, and environmental decisionmaking, which can be a powerful and transformative experience.

Most of the citizen science examples we highlight capitalize on synergies between science acquisition and public input and engagement. For example, volunteers help monitor birds at scales impossible to do otherwise and also promote bird conservation (Case Studies 1 and 7); through their observations-and sometimes action-volunteers take on local problems that scientists and officials had overlooked, contributing to both science and decisionmaking (Case Studies 2 and 5); and a federal agency encourages diverse stakeholders to engage in identifying science and management goals and then participate in the monitoring and adaptive management process (Case Studies 3 and 4).

Perhaps the greatest potential for synergies is when citizen science contributes to an adaptive management process, which often engages a variety of stakeholders and the public. In adaptive management, problems are assessed; management actions are designed and implemented; and management outcomes are monitored, evaluated, and adjusted as necessary in an iterative cycle. The success of adaptive management is measured by how well it increases scientific knowledge, helps meet management goals, and reduces conflict among stakeholders (Aceves-Bueno et al., 2015). 
Despite its utility, adaptive management can be difficult to implement because of time constraints, lack of funding, and other limitations. Citizen science can facilitate adaptive management, especially when the monitoring is appropriate for volunteers and when the management issue in question is of local interest. For example, the National Park Service is working with local organizations and volunteers in and around Acadia National Park in Maine to use citizen science as part of an adaptive management approach to maintaining and improving the resilience of ecosystems facing rapid environmental change, particularly climate change, invasive species, and air and water pollution (Babson, 2014). Without volunteers, the park staff and professional scientists would not be able to accomplish the necessary monitoring of wildlife, invasive plants, and water quality. Many of the same volunteers and organizations are also engaged in decisionmaking processes regarding park management.

\subsection{What investments does citizen science require?}

Although citizen science relies on volunteers, it is not free. An organization or primary investigator must invest time and money for a citizen science project to succeed. It requires investments in personnel (both staff and volunteers) and in all the tools and other resources that volunteers need to successfully carry out the project.

Initial investment in citizen science can save on overall costs to an organization (Gardiner et al., 2012). Federal, state, and local agencies and non-governmental organizations already depend heavily on volunteers for various types of services; some organizations have several volunteers for every paid employee. The educational system in the United States at both the high school and college levels stresses community service, creating a large pool of potential volunteers for citizen science. Organizations can take advantage of such opportunities (Case Study 6), enlisting volunteers to accomplish tasks that would be impossible for staff alone. For example, Paleo Quest, a citizen science program where volunteers scour various landscapes for fossils, found that having volunteers assist in field work increased its scientific productivity and reduced its cost per scientific paper from tens or hundreds of thousands of dollars to sometimes less than a thousand dollars (Regan, 2014). Theobald and colleagues found that, in a subset of 388 biodiversity monitoring projects, over 1.3 million volunteers were contributing up to $\$ 2.5$ billion in kind annually (Theobald et al., 2015).

The precise investments needed depend on the particular goals, scale, and scope of the project (Tulloch et al., 2013). Small-scale projects require little to no organizational investment and can be led by a single investigator, with a small team of volunteers to collect samples; a single citizen science volunteer might have the knowhow and resources to conduct and publish research alone. Larger projects and projects with multiple goals often require thoughtful investment by organizations, which often underestimate the requirements of citizen science projects. To be effective, a project must have a sound scientific design and a method for recruiting, training, and retaining volunteers (Domroese and Johnson, 2016). The project must also gather, store, and analyze data and communicate the results. A citizen science project must do everything a conventional science project does while also engaging volunteers, which can require special expertise and always takes time and resources. Some citizen science projects require fewer resources than a comparable conventional science project, but some require more. In large projects and through partnerships, organizations can take advantage of economies of scale.

A citizen science project usually needs a trained scientist to ensure rigorous experimental design, quality control and assurance, and use of accepted standard analytical and statistical techniques. Projects may also need a skilled multi-disciplinary team to furnish tools necessary to implement a project, provide a system for evaluating the quality of the project, and foster public input and engagement. In general, no one person knows enough about every aspect of a citizen science project or has the time to run the project alone. Having both social and biophysical scientists and specialists working together on the same team can improve research outcomes for both science and management while also improving the design of future projects.

Furnishing tools for citizen science projects is also important. The tools needed depend on a project's goals, technology, information management systems, data policies and guidelines, and communication systems. In many cases, organizations and scientists can use or modify existing projects or tools-for example, asking volunteers to use eBird to monitor bird populations (Case Study 7). In other cases, organizations and scientists might need to develop entirely new tools and the supporting infrastructure. For example, they might need to designate staff to research appropriate data collection methods; to develop a database for accessing, archiving, and analyzing data; and to recruit and train volunteers. CitizenScience.org lists many of the tools available and the steps that should be considered when planning a citizen science project.

Citizen science projects also require evaluations of the process and measurements of outcomes. Is the process engaging the right people and generating the right data? Are volunteers engaged, and do they remain involved? Are the goals for science and public input and engagement being met? The evaluation systems can be internal or external to a project or organization, but ideally the results feed back into the project through an adaptive management system and improve the project's implementation. An expanding suite of reports, peerreviewed papers, and other resources describes methods for evaluating projects and their outcomes and provides techniques for designing projects in ways that facilitate their evaluation (e.g., https:// crowdsourcing-toolkit.sites.usa.gov/).

\subsubsection{Investments in data management}

To ensure data quality, access, and transparency, rigorous data management must be in place. Publicly available data are still a small fraction of the data that exist, and although data repositories are becoming more common, scientific data are scattered far and wide (Newman et al., 2011; Newman et al., 2012). Even the publicly accessible data can be hard to access if they are shielded by publishers or need to be translated into digital formats for redistribution and broader use. Even when "open" data can be easily downloaded, they rarely come with adequate documentation of data collection and analysis methods, information on important caveats (e.g., appropriate level of inference and presence of questionable data), and instructions for appropriate use and citation.

Citizen science is a notable exception in that data are often more readily shared (Sullivan et al., 2016), but they still fall prey to many of the same problems as conventional research data. Poorly documented data can be impossible to interpret appropriately and use responsibly. If data users do not know how the data were collected or details about data quality processes, they might judge the data to be useless or make inappropriate assumptions. DataONE is developing resources for citizen science project organizers and professional scientists alike to help them better manage, document, and share their data. Practitioner guides to data management are increasingly available (see DataONE. org and CitizenScience.org).

\subsubsection{Investments to navigate federal policy considerations}

For citizen science projects that involve federal agencies and depend on the federal role in the project, federal policy considerations might apply (Gellman, 2015; Smith, 2014). Such policy considerations include intellectual property, privacy, and the special obligations of federal agencies under the law.

Intellectual property concerns include data ownership and access (Gellman, 2015; Scassa and Chung, 2015). Organizations can deal with such concerns by crafting terms-of-use and user agreements. The agreements specify the roles and responsibilities of the organizations and participants with respect to citizen-generated data. However, resources will be needed to ensure compliance with laws.

Privacy concerns revolve around personal and location-based information as well as photographs, videos, and audio files, all of which are 
governed by the Privacy Act (Bowser et al., 2014; Gellman, 2015). Federal agencies that carry out citizen science projects have two options for complying with the Privacy Act: (1) they can avoid collecting personally identifiable information about volunteers and avoid using databases that retrieve data based on personally identifiable information; or (2) they can set up a process for handling personally identifiable information and have it reviewed and approved by the Office of Management and Budget (OMB). Some citizen science programs have found technological ways of eliminating personally identifiable information from their databases.

Citizen science projects also ask volunteers to record standardized observations and submit them on data sheets or online forms. For projects involving federal agencies, this can trigger the Paperwork Reduction Act, intended to reduce the burden of paperwork for the public (Gellman, 2015). The act applies to federally sponsored or conducted work, including scientific research. It requires federal agencies to examine what information volunteers are asked to provide and to issue a request for public comment relating to the justifications for and estimates of the burden. The process typically takes several months to more than a year. Agencies generally anticipate this "cost of doing business" and plan accordingly. However, these long lead times can limit the utility of citizen science for events that require a rapid response, such as oil spills, volcanic eruptions, and wildfires. For such events, federal agencies might need to rely on existing OMB-approved projects, projects that can be fast-tracked through the clearance process, or projects that do not require $\mathrm{OMB}$ approval.

Under the Data Quality Act (sometimes called the Information Quality Act), federal agencies are required to ensure that the data they disseminate meet standards for quality, utility, objectivity, and integrity (Gellman, 2015). The OMB and the agencies themselves write the corresponding guidelines, which apply to both citizen science and conventional science.

\subsubsection{Investments in citizen science as a whole}

Broader investment in the field of citizen science as a whole is also needed to spur innovation and the development and adoption of best practices. Investments are needed in shared resources, particularly tools for planning and carrying out citizen science projects, and in platforms for fostering communication across projects and disciplines. Such investments will cut costs, reduce the time it takes to generate results, and facilitate growth and maturity in the field of citizen science. A recent example of such an investment is the Federal Crowdsourcing and Citizen Science Toolkit (https://crowdsourcing-toolkit.sites.usa.gov/), which aims to advance the use of citizen science in the federal community. It provides links to many different resources, including step-bystep directions for planning and implementing citizen science projects; case studies; and information about who is conducting citizen science projects and where those projects occur.

There are multiple areas in particular that would greatly benefit from investment. These include developing a shared protocol library (such as the National Environmental Methods Index) and encouraging the use of common data standards (such as for water quality monitoring) to maximize the value and durability of the data collected (Burgess et al., 2016). The North American Breeding Bird Survey is a prime example of the utility of standardized protocols and datasets (Case Study 1 ).

Investing in the development of sensor technology would improve the quality and lower the cost of data produced through citizen science projects. For example, lack of low-cost air quality monitoring technology has made community air quality monitoring lag behind volunteer monitoring in other areas, such as water quality. In response, the Environmental Protection Agency has launched the Next Generation Air Monitoring initiative to promote the development and use of low-cost portable air sensors that can produce the high-quality data needed to meet the agency's standards.

Investing in the development of techniques or tools to gather, share, and analyze large quantities of data collected by different projects across large areas will further improve the value of citizen science in tackling major challenges, such as tracking great migrations or documenting changes in species ranges (Dickinson et al., 2010; Munson et al., 2010). Assessments are underway to identify needs and develop strategies for meeting them. For example, CitSci.org is assessing needs, piloting technical solutions, and evaluating and refining the resulting tools in an effort to develop a customizable, reusable plugand-play package that provides much of the software needed to develop and run a citizen science project for natural resource management. Such efforts will minimize the need to develop independent software for each new citizen science project.

Citizen science-and science in general-also depend on effective collaboration. Investments are needed in social and organizational structures and policies to improve the communication of data, and facilitate awareness of best practices in and innovation by citizen science projects. One example of a group seeking to improve communication is the international Citizen Science Association, which brings together universities, government groups, and non-governmental organizations that invest in citizen science with the broad community of citizen science researchers, educators, and practitioners. Various agencies are developing complementary coordination networks (Case Study 8). These networks help meet communication needs; provide points of entry for people new to the field; and promote best practices and professional development while providing project evaluation and other supporting services. The Citizen Science Association also aims to attain high standards of scientific rigor in citizen science projects and provide opportunities for professional development. However, most of the coordination networks are very new and need more funding and other support.

Finally, citizen science centers could bring together various disciplines, such as conservation, public health, and biochemistry, to promote citizen science standards, technology, data collection and analysis, and communication. A center (virtual or physical) for citizen science on natural resource management and environmental protection could bring together leaders operating at different scales (from global to individual protected areas) to develop solutions to shared and complex problems. Solutions could include integrating data across projects; creating visualizations and other data products that are useful to managers, decisionmakers, and the public; evaluations or systematic reviews of techniques to enhance science, management, or engagement outcomes; and efficient methods for planning, implementing, and sustaining projects that involve multiple organizations. The USA National Phenology Network (Case Study 8) is a successful model of a citizen science center.

\section{Conclusions}

Although humans have triggered the current conservation and environmental crises, we also possess the capacity to discover, innovate, and act for a more sustainable future. Engaging greater numbers of people in science can increase our understanding of Earth's systems and find culturally and politically feasible solutions to problems. Citizen science is not a panacea, and further research is needed to better understand how citizen science can build understanding and deliver positive outcomes. However, citizen science does represent a promising option for tackling serious challenges in the fields of conservation biology, natural resource management, and environmental protection. Citizen science is already contributing to science and natural resource and environmental management and policymaking. Every year, tens of thousands of volunteers take to the forests, grasslands, wetlands, coasts, lakes, streams, and even their own backyards to provide high-quality, usable scientific information. Many large and longstanding projects would not be possible without volunteers who produce long-term datasets, collect data over large geographic areas, detect rare events and species, and address areas of research that would otherwise be neglected. Citizen science has made clear contributions to science, contributing to many peerreviewed publications and extensive datasets that natural resource 
and environmental managers need. Citizen science increases the potential for serendipitous knowledge discovery and creates information that goes into policy formulation, planning, and management activities at various levels of government.

Citizen science also provides benefits beyond science, offering the opportunity for an open discourse based on scientific knowledge that more people can access, understand, and trust. Through citizen science, conservation efforts benefit from partnerships and from broad public perspectives, including local and traditional knowledge. Citizen science can increase scientific and environmental literacy and extend public involvement in decisionmaking by natural resource and environmental managers and other decisionmakers. Citizen science can help identify patterns and gaps and help set priorities and allocate resources. By spreading scientific knowledge and engaging more people in policy formulation, citizen science can help reach solutions that lead to better environmental and social outcomes and avoid unnecessary conflict.

\section{Acknowledgments}

Funding for this project was provided by Cooperative Agreement 12 CA-11221633-096 between the U.S. Forest Service and the Ecological Society of America (ESA). The National Park Service and the Schoodic Institute at Acadia National Park provided other funding and services. We would like to thank Kevin Bryan at the Meridian Institute for facilitating the workshops. We also thank Cliff Duke, Jennifer Riem, and Jill Parsons at ESA for logistical support. The views expressed in this paper do not necessarily represent the views of the U.S. government or any of its departments, with the exception of the U.S. Geological Survey. Any use of trade, product, or firm names is for descriptive purposes only and does not imply endorsement by the U.S. government.

\section{Appendix A}

Case Study 1

North American Breeding Bird Survey.

Spatial range: Temporal range: Long Level of training: Basic, but Local to national term ( $>10$ years) engages experienced birders

History: Established in 1966, the BBS is a cooperative effort between the U.S. Geological Survey's (USGS's) Patuxent Wildlife Research Center and Environment Canada's Canadian Wildlife Service (ECCWS) to monitor the status and trends of North American bird populations.

Management goals: The main goal of the program is species management by monitoring changes in bird populations and distributions across North America and informing researchers and wildlife managers of significant changes.

Level of volunteer participation in scientific process: Volunteers conduct bird surveys and enter the information collected into a professionally managed online database, but they do not formally participate in project design or in analysis and interpretation of the data.

Level of volunteer participation in public involvement: Public engagement is not a central focus, although the project might stimulate public action.

Sustainability: Professional managers, coordinators, researchers, and statisticians compile, curate, analyze, and deliver volunteer-collected information to policymakers, managers, and the general public. Researchers and the general public have free access to processed data in perpetuity.

Science: Data generated by the BBS have contributed to over 500 peer-reviewed papers.

Public input and engagement: Educators use BBS data for basic instruction in a number of scientific disciplines.

Investment: The project has long-term funding through the USGS and ECCWS. Additional funding from other sources supports researchers' use of data for publication.

Outcomes/outputs/benefits: An analysis of BBS citations in the Federal Register (the daily journal that records and documents federal actions) shows that BBS data are used in many policy decisions, including in the implementation of far-reaching legislation such as the Endangered Species Act, the Migratory Bird Treaty Act, and the National Environmental Policy Act. For example, the Federal Register cited the BBS in a Petition to List Two Populations of Black-Backed Woodpecker as Endangered or Threatened (April 2013), a proposal for endangered status for the Gunnison sage-grouse (January 2013), and a proposal to list the streaked horned lark as threatened and to designate critical lark habitat (October 2012) (can be accessed at www.regulations.gov).
The following quotes reflect the value of the BBS to decisionmakers:

We conclude that, while the BBS is the only long-term trend information available for the mountain plover on its breeding range, it is an imprecise indicator of mountain plover population trends. ... Even so, we acknowledge that this is the best available information on trends for this species and BBS survey results suggest a recent (1999 through 2009) moderated rate of decline. (U.S. Fish and Wildlife Service, from the withdrawal of the petition to list the mountain plover as threatened, May 2011)

$[L]$ ong-term estimates of Sprague's pipit abundance have come from the Breeding Bird Survey (BBS), a long-term, large-scale survey of North American birds that began in 1966. The BBS is generally conducted by observers driving along set routes. ... Since there is some evidence that Sprague's pipits avoid roads (Sutter et al. 2000, p. 114), roadside surveys may not be the best measure of abundance of Sprague's pipits, for example. Nonetheless, the methods of the BBS have been consistent through time, and the $B B S$ provides the best available trend information at this time. (U.S. Fish and Wildlife Service, from the 90-Day Finding on a Petition to List Sprague's pipit as Threatened or Endangered, December 2009)

\section{Case Study 2}

Volunteer water monitoring: Natural resource and environmental policy outcomes.

Spatial range: Local to Temporal range: Long term Level of training: Basic to national ( $>10$ years $) \quad$ extensive

History: Program coordinators of U.S. volunteer water monitoring programs were surveyed in 2013, with the survey covering 345 programs supporting more than 1300 subprograms. The scope of volunteer water monitoring programs varies: about $40 \%$ monitor a single water body or watershed, and about half operate statewide or across multiple watersheds. Fewer programs operate across state lines or nationally. Programs were initiated between 1965 and 2012. Nearly half have been collecting data for more than 16 years.

Management goals: Fifty-one percent of the 296 respondents indicated that one of their program objectives was to obtain data for use in effecting change to natural resource and environmental policy (Fig. 2, top panel), and a third reported having used the data collected for just this purpose.

Level of volunteer participation in science: About three-quarters of the survey respondents indicated using data collected by volunteers to develop, change, or enforce a policy or regulation. In one instance, volunteer data from a 32-year-old program became the sole source of water quality data for the natural resources agency due to budget cuts.

Outcomes/outputs/benefits: Most used the data to affect outcomes at the state and local levels (Fig. 2, bottom panel). Examples include the development of ordinances to stop shoreline waterfowl feeding; create oyster sanctuaries; require mandatory pet waste cleanup in specified areas; expand ultraviolet disinfection periods at a wastewater treatment plant; and require slow zones or no-wake zones for boats to minimize the spread of invasive species. The programs also used data to identify faulty septic systems, improper wastewater treatment plant discharges, illegal connections in municipal stormwater systems, and (in an impressive $67 \%$ of all cases) failure to meet water quality standards. These data also contributed to listings of impaired waters and to definitions of total maximum daily loads (TMDLs) for state reporting to EPA under the Clean Water Act (TMDLs describe allocation limits for pollutants in water bodies). Dam owners, city and county stormwater districts, wastewater treatment plants, and individuals required to comply with forestry best management practices have had permits altered based on results of volunteer monitoring. Moreover, additional monitoring has been required by permittees. Among other factors, program age was significantly related to increased natural resources policy and management outcomes at larger geographic scales. These examples clearly show that citizen science can contribute to natural resource and environmental policy and management.

\section{Case Study 3}

The U.S. Forest Service's new planning rule.

\begin{tabular}{cll}
\hline $\begin{array}{c}\text { Spatial range: Local to } \\
\text { national }\end{array}$ & $\begin{array}{l}\text { Temporal range: Long term } \\
(>10 \text { years })\end{array}$ & $\begin{array}{l}\text { Level of training: Basic to } \\
\text { extensive }\end{array}$
\end{tabular}

History: The U.S. Forest Service manages 193 million acres of forest, grassland, and other ecosystems. The National Forest Management Act requires each national forest or grassland to adopt a long-term management plan designed to guide projects and other management activities over a 10- to 15-year period. An agencywide planning rule is used to guide development of resource management plans. In 2012, the Forest Service adopted a new rule for land management planning (United States Department of Agriculture, 2011). The new rule recognizes that scientific knowledge, though essential, is not the exclusive basis for effective management of the National Forest System. The rule calls on Forest Service units to utilize local and traditional knowledge. It also directs each unit to engage the public at the beginning of its planning process for maximum transparency.

Management goals: The Forest Service's fundamental goal is maintaining and restoring ecosystem and watershed health and resilience in order to protect water, air, soil, and other resources. The planning rule calls for monitoring

(continued on next page) 


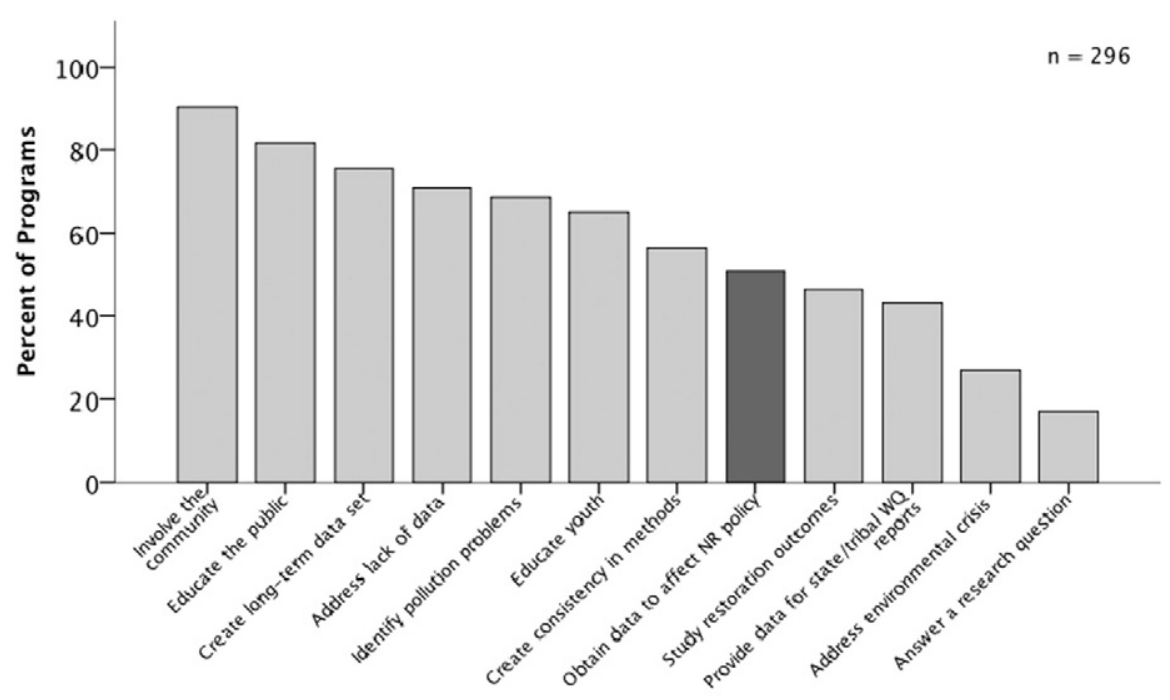

Objective
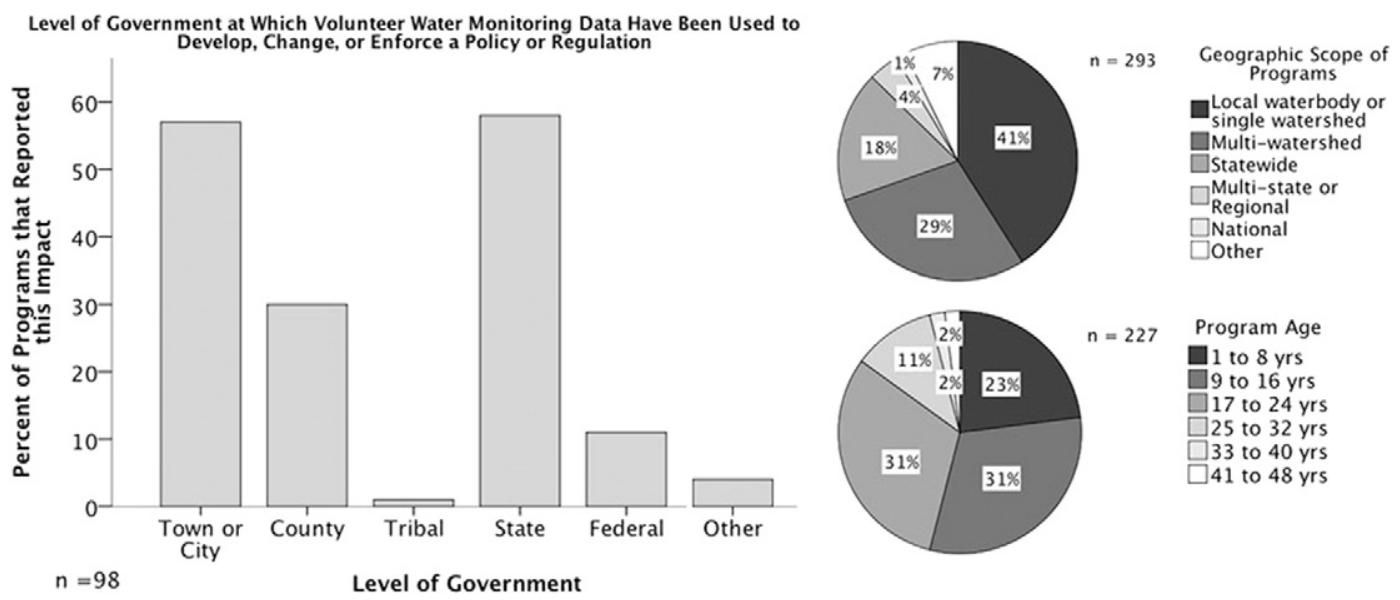

Program Age

G to 8 yrs

9 to 16 yrs

17 to $24 \mathrm{yrs}$

25 to 32 yrs

33 to 40 yrs

41 to 48 yrs

Level of Government

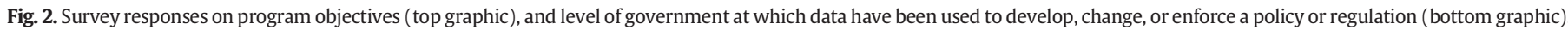
Inset A (bottom graphic): geographic scope of monitoring programs. Inset B (bottom graphic): distribution of program ages.

species diversity and viability, activities that are particularly well suited to citizen science. Satisfying such robust science needs in support of management proposals might only be possible with volunteers.

Level of volunteer participation in science: The public and volunteers associated with nongovernmental organizations provide substantial input on what to monitor. Volunteers monitor a wide range of ecological, social, and economic indicators in order to provide feedback that natural resource managers can use in the planning process.

Science: Because the planning rule is new and only now being implemented, volunteers are still collecting the data required for the science outcomes that land managers need. The type of monitoring has expanded to include effectiveness (management goals) and validation monitoring (test hypothesis) in addition to the implementation monitoring (projects/targets) that the agency has been doing for decades.

Public input and engagement: The 2012 planning rule calls on Forest Service units to utilize local and traditional knowledge in addition to the best available science in planning their management activities. The planning rule directs each unit to engage the public at the beginning of its planning process for maximum transparency. In addition, it calls for collaboration with the public in identifying what to monitor, and it encourages public participation in the monitoring process to assess the ecological, economic, and social impacts of management actions.

Investment: Funding for the Forest Service's land and resource management planning and forest plan implementation is provided by the federal appropriations process on an annual basis. In some cases, partnerships with other organizations are important, including with non-governmental organizations and industry groups.

Outcomes/outputs/benefits: The planning rule presents new opportunities to engage the public beyond existing requirements for public notices and formal processes. In addition, by encouraging citizen engagement early on in the planning process, the new rule creates direct opportunities for knowledge gained through citizen science to affect land management and public policy discussions. Citizen science (mainly through monitoring) can provide continuous information to meet science needs and possibly more capacity to respond to unplanned events, such as catastrophic wildfires and insect epidemics.

Case Study 4

The Collaborative Forest Landscape Restoration Program: Uncompahgre Plateau Project.

\begin{tabular}{cll}
\hline Spatial range: & Temporal range: Long term $(>10$ & Level of training: \\
Regional & years $)$ & Basic
\end{tabular}

History: The Collaborative Forest Landscape Restoration Program (CFLRP) encourages the collaborative, science-based restoration of high-priority forested landscapes managed by the U.S. Forest Service and its partners (Schultz et al., 2012). The program addresses the uncertainties of managing landscapes exposed to damaging wildfires. To minimize conflicts over management activities, the CFLRP involves a wide variety of local, state, and federal partners, as well as numerous private organizations, including environmental non-governmental organizations. The program has implemented 23 projects across the country using an adaptive management approach, with an emphasis on multiparty monitoring. A number of CFLRP projects use citizen science.

Management goals: The primary goal of the CFLRP is to reduce the risk of uncharacteristically severe wildfires and wildfire management costs by reestablishing natural fire regimes. For example, the Uncompahgre Plateau Project in Colorado calls for prescribed burning and reestablishing native vegetation in the Grand 
Mesa, Uncompahgre, and Gunnison National Forests. Citizen science volunteers are measuring key vegetation and wildlife variables before and after treatment and will continue to do so at specified intervals.

Level of volunteer participation in scientific process: Forest Service personnel typically conduct field measurements as part of normal operations, with help from outside experts (such as academic researchers) and citizen science volunteers. Partners (including local residents) are helping to formulate research questions and experimental design as part of adaptive management. Citizen science volunteers are organized by the Uncompahgre Partnership, a collaborative group that includes the Forest Service and other partners and guides project implementation.

Level of volunteer participation in public involvement: The project emphasizes collaborative decisionmaking, with multiple opportunities for public input. At monitoring meetings held at least twice a year, partners discuss monitoring priorities. By project design, citizen science is a major tool for public engagement.

Sustainability: The program's funding authority expires in 2019. The project's many partners contribute to project funding.

Science: Citizen science volunteers measure various ecological indicators, including ground cover, plant composition and height, and the presence of various plant and animal species. Science outcomes are used directly by the forest managers. Data are archived and published in technical reports and peer-reviewed scientific journals.

Public input and engagement: Public input is solicited early and often. The Forest Service and its partners engage the public throughout the adaptive management cycle, from issue identification, to decisionmaking, to monitoring of project outcomes. Public input also comes from the usual formal processes, such as public comment periods.

Investment: Total funding for the Uncompahgre Plateau Project, including partner funds, was about $\$ 1.7$ million in fiscal year 2012 , with about $\$ 165,000$ allocated for monitoring activities. Monitoring is required during the project and for 15 years after its completion.

Outcomes/outputs/benefits: In 2012, the Uncompaghre project improved, restored, or enhanced 8202 acres of wildlife habitat, improved 1205 acres of forest vegetation, managed noxious and invasive plants on 222 acres, sold over 500,000 cubic feet of timber, decommissioned about 30 miles of roads, and reduced hazardous fuels on 771 acres in the wildland-urban interface.

Case Study 5

Clean Air Coalition of Western New York: Tonawanda air quality study.

$\begin{array}{cll}\text { Spatial range: } & \text { Temporal range: Short term (1-3 } & \text { Level of training: } \\ \text { Local } & \text { years) }\end{array}$

History: Tonawanda is an urban area in western New York with some of the state's largest industrial facilities.

Management goals: Concerned about smells and smoke, citizens suspected a connection to chronic health problems in their community. The goal was to identify the cause of the health problems with the hope of ultimately mitigating them.

Level of volunteer participation in science: Volunteers collected air samples using the bucket method to find out what was in the air.

Level of volunteer participation in public involvement: Volunteers, organized as the Clean Air Coalition of Western New York, presented their data to the New York Department of Environmental Conservation (DEC) and to the Environmental Protection Agency (EPA).

Sustainability: The coalition has moved on to other projects. According to its Website, "The Clean Air Coalition builds power by developing grassroots leaders who organize their communities to run and win environmental justice and public health campaigns in western New York."

Science: Following a standard protocol, the bucket takes a 3-minute "grab sample"-a single sample of air, at one point in time, with no other information collected. The study included such factors as wind speed and direction. Elevated levels of benzene, a known carcinogen, were found to be above the DEC's health-based annual guideline concentrations.

Public input and engagement: Citizens articulated community concerns and presented air quality data to state and federal regulatory agencies. The evidence collected by the citizens and subsequent public input to the DEC were compelling enough to warrant the attention of the agencies.

Investment: The initial volunteer-led project did not require any agency investment. Based on results from the citizen science project, the New York DEC used funding from an EPA Community-Scale Air Toxics Ambient Monitoring Grant to undertake a year-long study of the air quality in Tonawanda using EPA air monitors.

Outcomes/outputs/benefits: Spurred by what the citizens initially found, the DEC used air monitors at four locations to measure 56 air toxins. Its year-long investigation formed the basis for compliance monitoring and regulatory actions by EPA and the New York DEC. As a result, the Tonawanda Coke Corporation agreed to improve operations, monitor for leaks, and upgrade pollution controls, decreasing benzene levels in the air by $86 \%$.
Case Study 6

Strategic investment in citizen science: The Wisconsin Citizen-Based Monitoring Network.

Spatial range: Temporal range: Long term Level of training: Basic to

State (>10 years) extensive

History: The community of professionals and volunteers engaged in monitoring natural resources and the environment in Wisconsin formed the Wisconsin Citizen-Based Monitoring (CBM) Network. The network is made up of CBM practitioners from over 150 programs representing an array of organizations, including primary and secondary schools; county, state, and federal agencies; nature centers; conservation clubs; land trusts; and other nongovernmental organizations.

Management goals: This comprehensive group of stakeholders is collaborating to improve the efficiency and effectiveness of monitoring throughout the state.

Level of volunteer participation in science: Wisconsin Department of Natural Resources (WDNR) supports an advisory council drawn from volunteer groups. The council works with the department to identify monitoring priorities, help evaluate the effectiveness of the network, and ensure agency responsiveness to network needs.

Public input and engagement: Wisconsin's state-supported network for citizen science helps engage and inform thousands of students and citizens every year, broadening public support for the state's conservation goals.

Investment: The network is coordinated and supported by WDNR. A WDNR employee serves as full-time network coordinator, and the department invests $\$ 100,000$ each year in small ( $\$ 5000$ ) competitive contracts for CBM projects that meet high-priority needs for data. In addition, 10 to 20 department scientists also lead individual projects or provide advice.

Outcomes/outputs/benefits: Through these investments, the state is able to meet its data needs over much larger areas and timespans than could be covered by staff scientists alone. Financial support for the network allows the state to stretch its limited conservation dollars; for every $\$ 1$ spent on CBM contracts, the state receives more than $\$ 3$ worth of volunteer time.

\section{Case Study 7}

Using existing citizen science tools: eBird and iNaturalist.

Spatial range: $\quad$ Temporal range: Long Level of training: Basic, online,
Local to national term ( $>10$ years) or workshop training

History: Many citizen science programs facilitate collection of data important for natural resource management and environmental protection organizations. In recent years, the National Park Service and U.S. Fish and Wildlife Service have encouraged volunteers to use eBird and iNaturalist to record observations of birds and other species in national parks and wildlife refuges. These programs have online interfaces that volunteers can use to submit data, and they provide data storage, curation, and quality control services. They help parks and refuges solve one of their most basic science and management problems: tracking the identity and abundance of species (Fig. 3).

Management goals: Parks and refuges use these programs to keep up-to-date information on the species that occur on their lands and to monitor changes in their abundance and life cycles.

Level of volunteer participation in scientific process: Participants in both eBird and iNaturalist primarily record observations of species in the field. Participants can also explore online visualization and analysis tools.

Level of volunteer participation in public involvement: Many parks and refuges use these programs to develop relationships with local volunteers who already have or will develop expert knowledge on local biodiversity. Park and refuge staff can later turn to these volunteers for information and input related to management decisions.

Sustainability: The projects are generally sustainable as long as the park or refuge is able to train, coordinate, and retain volunteers. By using existing online infrastructures, the parks and refuges greatly reduce project costs.

Science: eBird and iNaturalist have been utilized in dozens of peer-reviewed papers and national assessments, such as reports on the state of birds on public and private lands.

Public input and engagement: Parks and refuges use these programs to encourage public input and engagement in management decisions, as appropriate. For example, a refuge might ask its most active eBird volunteers to comment on management decisions that affect bird habitat.

Investment: Parks and refuges train and coordinate volunteers. They also invest in other activities, such as national training for park and refuge staff; the deployment of kiosks or displays to facilitate volunteer recruitment, data entry, and education; and development of techniques to integrate citizen science data into agency data management structures, such as NPSpecies, the system that national parks use to track species within their borders (irma.nps.gov/NPSpecies/).

Outcomes/outputs/benefits: By using citizen science programs, refuges and parks can affordably meet some of their most basic monitoring needs. Programs like eBird and iNaturalist already engage tens of thousands of volunteers and generate hundreds of millions of observations. They provide data that park and refuge staff can use in making a variety of management decisions. Volunteers can also become important resources for park and refuge managers as sources of expertise on local biodiversity. 

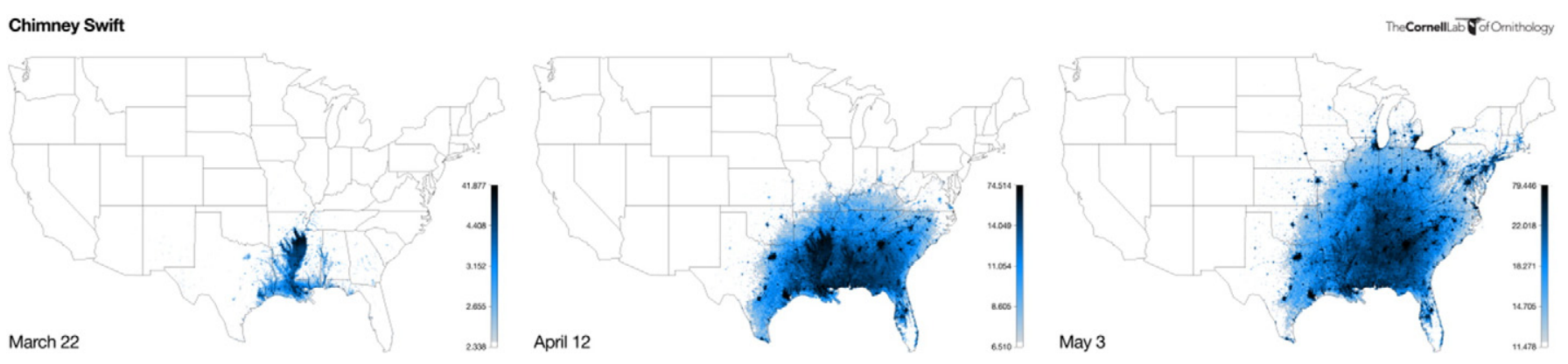

Fig. 3. Heat maps show the northward migration of the chimney swift as modeled by the eBird network. Darker colors indicate higher probabilities of finding the species (Courtesy of the Cornell Lab of Ornithology). The analysis is based on presence-absence data from complete checklists collected under the "traveling count" and "stationary count" protocols from January 1 , 2004 to December 31, 2011 within the conterminous United States. The species distribution models were trained using one species at a time, with each based on 1,533,267 checklists made across 238,865 unique locations within this area.

\section{Case Study 8}

Investing in capacity: The USA National Phenology Network.

Spatial range: Temporal range: Long Level of training: Basic, online,
Local to national term ( $>10$ years) or workshop training
History: Changes in the timing of seasonal events, such as flowering, migrations,
and breeding, amount to some of the most sensitive biological responses to
climate change. Such changes in timing can affect ecosystems, causing
mismatches between plants and their pollinators or disruptions in
predator-prey interactions, and they can alter the timing of management
actions, such as invasive species control. Until recently, however, there have
been few monitoring or research programs focused on the topic. The USA Na-
tional Phenology Network (USA-NPN) is a nationwide science and monitoring
initiative focused on phenology (the study of events in the life cycles of plants
and animals and changes in their timing). Stakeholders include researchers,
resource managers, educators, and the public. The network relies on both con-
ventional and citizen science.
Management goals: The USA-NPN seeks to enhance scientific understanding of
phenology, improve decisionmaking using phenological data and information,
support adaptive natural resource management and environmental protection,
facilitate societal adaptation to environmental variation and change, and im-
prove public understanding of climate change and the science of phenology.
Level of volunteer participation in scientific process: Participants in Nature's
Notebook, the multi-taxa phenology-observing program run by the network to
collect data observed on the ground, include both volunteers and professional
scientists and managers. Participants record phenology of plants and animals
according to standardized published protocols and enter the data into a profes-
sionally managed database. Other governmental and non-governmental organi-
zations use Nature's Notebook for information while contributing their own data
to the broader effort. In early 2014 , network staff estimated that about half of the
data in Nature's Notebook came from professionals and professionally trained
participants and the other half from individuals or small volunteer groups par-
ticipating in the project. The professionals and volunteers use the same protocols
for monitoring.

Level of volunteer participation in public involvement: Public engagement in data collection is key to the network, as are education and outreach. Public involvement in resource management and policymaking, though of secondary importance, does happen as a part of partner projects, for example where phenology monitoring is part of local conservation projects.

Sustainability: The network's national coordinating office, operated in cooperation with University of Arizona, is almost entirely federally funded. The project has long-term funding from the U.S. Geological Survey. Additional funding from other sources, both governmental and non-governmental, supports expansion of operations; the production of tools (such as mobile applications and custom Websites); and research, development, and delivery of products for a variety of purposes. Researchers and the general public have free and easy access to raw and processed data in perpetuity.

Science: Data and data products generated by the USA-NPN have been used in seven peer-reviewed publications to date. The USA-NPN facilitates a community of practice among phenology researchers, identifies the needs of resource managers and environmental protection specialists for data and decision support tools, and communicates new insights.

Public input and engagement: The USA-NPN does not directly seek public input and engagement in management decisions, but many partner projects do. The USA-NPN infrastructure establishes science methods and tools and lets local organizations focus on conservation applications and engagement.

Investment: The U.S. Geological Survey and other organizations provide about \$1 million per year to the network. Many local, regional, and national partners leverage the network's central infrastructure and make their own investments for research, management, and education applications.
Outcomes/outputs/benefits: To maximize limited resources, the network was designed as a national framework for phenology science and monitoring. Other governmental and non-governmental organizations leverage its capacity for their own applications while contributing to the national dataset. Applications include identification of wildlife species vulnerable to climate change, parameterization and validation of models of carbon sequestration and water cycling, management of invasive species, planning of seasonal cultural activities, forecasting seasonal allergens, managing agricultural production on working farms and ranches, and tracking disease vectors between continents and in human population centers.

\section{References}

Aceves-Bueno, E., Adeleye, A.S., Bradley, D., Brandt, W.T., Callery, P., Feraud, M., Garner K.L., Gentry, R., Huang, Y., McCullough, I., Pearlman, I., Sutherland, S.A., Wilkinson, W., Yang, Y., Zink, T., Anderson, S.E., Tague, C., 2015. Citizen science as an approach for overcoming insufficient monitoring and inadequate stakeholder buy-in in adaptive management: criteria and evidence. Ecosystems 18, 493-506.

Allen, R.M., 2012. Transforming earthquake detection? Science 335, 297-298.

Altizer, S., Hochachka, W.M., Dhondt, A.A., 2004. Seasonal dynamics of mycoplasmal conjunctivitis in eastern North American house finches. J. Anim. Ecol. 73, 309-322.

Arlettaz, R., Schaub, M., Fournier, J., Reichlin, T.S., Sierro, A., Watson, J.E.M., Braunisch, V. 2010. From publications to public actions: when conservation biologists bridge the gap between research and implementation. Bioscience 60, 835-842.

Armitage, D.R., Plummer, R., Berkes, F., Arthur, R.I., Charles, A.T., Davidson-Hunt, I.J., Diduck, A.P., Doubleday, N.C., Johnson, D.S., Marschke, M., McConney, P., Pinkerton, E.W., Wollenberg, E.K., 2009. Adaptive co-management for social-ecological complexity. Front. Ecol. Environ. 7, 95-102.

Babson, A.L., 2014. Overview of Climate Change Adaptation Needs, Opportunities, and Issues. Northeast Region Coastal National Parks.

Ballard, H.L., Huntsinger, L., 2006. Salal harvester local ecological knowledge, harvest practices and understory management on the Olympic Peninsula, Washington. Hum. Ecol. 34, 529-547.

Ballard, H.L., Fernandez-Gimenez, M.E., Sturtevant, V.E., 2008. Integration of local ecological knowledge and conventional science: a study of seven community-based forestry organizations in the USA. Ecol. Soc. 13.

Ballard, H.L., Dixon, C.G.H., Harris, E.M., 2016. Youth-focused citizen science: examining the role of environmental science learning and agency for conservation. Biol. Conserv. (Citizen Science Special Issue).

Balmford, A., Cowling, R.M., 2006. Fusion or failure? The future of conservation biology. Conserv. Biol. 20, 692-695.

Barnard, P., Altwegg, R., Ebrahim, I., Underhill, L.G., 2016. Early warning systems for biodiversity in southern Africa - how much can citizen science mitigate imperfect data? Biol. Conserv. (Citizen Science Special Issue).

Betts, M.G., Mitchell, D., Dlamond, A.W., Bety, J., 2007. Uneven rates of landscape change as a source of bias in roadside wildlife surveys. J. Wildl. Manag. 71, 2266-2273.

Bhattacharjee, Y., 2005. Ornithology - citizen scientists supplement work of Cornell researchers - a half-century of interaction with bird watchers has evolved into a robust and growing collaboration between volunteers and a leading ornithology lab. Science 308, 1402-1403.

Bikhchandani, S., Hirshleifer, D., Welch, I., 1992. A theory of fads, fashion, custom, and cultural-change as informational cascades. J. Polit. Econ. 100, 992-1026.

Bonney, R., Cooper, C.B., Dickinson, J., Kelling, S., Phillips, T., Rosenberg, K.V., Shirk, J., 2009. Citizen science: a developing tool for expanding science knowledge and scientific literacy. Bioscience 59, 977-984.

Boudreau, S.A., Yan, N.D., 2004. Auditing the accuracy of a volunteer-based surveillance program for an aquatic invader Bythotrephes. Environ. Monit. Assess. 91, 17-26.

Bowser, A., W. A., Shanley, L., P. J., Henderson, S., 2014. Sharing data while protecting privacy in citizen science. IX Interact. 70-73.

Brossard, D., Lewenstein, B., Bonney, R., 2005. Scientific knowledge and attitude change: the impact of a citizen science project. Int. J. Sci. Educ. 27, 1099-1121.

Brussard, P.F., Reed, J.M., Tracy, C.R., 1998. Ecosystem management: what is it really? Landsc. Urban Plan. 40, 9-20. 
Burgess, H., DeBey, L.B., Froehlich, H.E., Schmidt, N., Theobald, E.J., Ettinger, A.K. HilleRisLambers, J., Tewksbury, J., Parrish, J.K., 2016. The science of citizen science: exploring barriers to use as a primary research tool. Biol. Conserv. (Citizen Science Special Issue).

California Academy of Sciences, 2012. California Biodiversity Citizen Science Meetings. California Academy of Sciences, San Francisco, CA.

Carbayo, F., Marques, A.C., 2011. The costs of describing the entire animal kingdom. Trends Ecol. Evol. 26, 154-155.

Chandler, M., Rullman, S., Cousins, J., Esmail, N., Begin, E., Venicx, G., Eisenberg, C., Studer, M., 2016. Ecological and social outcomes from 7 years of citizen science evaluation: an Earthwatch case study. Biol. Conserv. (Citizen Science Special Issue).

Chen, I.C., Hill, J.K., Ohlemuller, R., Roy, D.B., Thomas, C.D., 2011. Rapid range shifts of species associated with high levels of climate warming. Science 333, 1024-1026.

Chess, C., Purcell, K., 1999. Public participation and the environment: do we know what works? Environ. Sci. Technol. 33, 2685-2692.

Clark, J.A., Hoekstra, J.M., Boersma, P.D., Kareiva, P., 2002. Improving U.S. Endangered Species Act recovery plans: key findings and recommendations of the SCB recovery plan project. Conserv. Biol. 16, 1510-1519.

Conrad, C.C., Hilchey, K.G., 2011. A review of citizen science and community-based environmental monitoring: issues and opportunities. Environ. Monit. Assess. 176, 273-291.

Cooper, C.B., Dickinson, J., Phillips, T., Bonney, R., 2007. Citizen science as a tool for conservation in residential ecosystems. Ecol. Soc. 12, 11.

Cooper, S., Khatib, F., Treuille, A., Barbero, J., Lee, J., Beenen, M., Leaver-Fay, A., Baker, D., Popovic, Z., Players, F., 2010. Predicting protein structures with a multiplayer online game. Nature 466

Cornwall, A., Jewkes, R., 1995. What is participatory research? Soc. Sci. Med. 41, 1667-1676.

Couvet, D., Jiguet, F., Julliard, R., Levrel, H., Teyssedre, A., 2008. Enhancing citizen contributions to biodiversity science and public policy. Interdiscip. Sci. Rev. 33, 95-103.

Crall, A.W., Newman, G.J., Stohlgren, T.J., Holfelder, K.A., Graham, J., Waller, D.M., 2011. Assessing citizen science data quality: an invasive species case study. Conserv. Lett. $4,433-442$.

Crall, A.W., Jordan, R., Holfelder, K., Newman, G.J., Graham, J., Waller, D.M., 2013. The impacts of an invasive species citizen science training program on participant attitudes, behavior, and science literacy. Public Underst. Sci. 22, 745-764.

Crowl, T.A., Crist, T.O., Parmenter, R.R., Belovsky, G., Lugo, A.E., 2008. The spread of invasive species and infectious disease as drivers of ecosystem change. Front. Ecol. Environ. $6,238-246$

Danielsen, F., Burgess, N.D., Balmford, A., 2005a. Monitoring matters: examining the potential of locally-based approaches. Biodivers. Conserv. 14, 2507-2542.

Danielsen, F., Jensen, A.E., Alviola, P.A., Balete, D.S., Mendoza, M., Tagtag, A., Custodio, C., Enghoff, M., 2005b. Does monitoring matter? A quantitative assessment of management decisions from locally-based monitoring of protected areas. Biodivers. Conserv. $14,2633-2652$

Danielsen, F., Mendoza, M.M., Tagtag, A., Alviola, P.A., Balete, D.S., Jensen, A.E., Enghoff, M. Poulsen, M.K., 2007. Increasing conservation management action by involving local people in natural resource monitoring. Ambio 36, 566-570.

Danielsen, F., Burgess, N.D., Jensen, P.M., Pirhofer-Walzl, K., 2010. Environmental monitoring: the scale and speed of implementation varies according to the degree of people's involvement. J. Appl. Ecol. 47, 1166-1168.

Danielsen, F., Jensen, P.M., Burgess, N.D., Altamirano, R., Alviola, P.A., Andrianandrasana, H., Brashares, J.S., Burton, A.C., Coronado, I., Corpuz, N., Enghoff, M., Fjeldsa, J. Funder, M., Holt, S., Hubertz, H., Jensen, A.E., Lewis, R., Massao, J., Mendoza, M.M. Ngaga, Y., Pipper, C.B., Poulsen, M.K., Rueda, R.M., Sam, M.K., Skielboe, T., Sorensen, M., Young, R., 2014. A multicountry assessment of tropical resource monitoring by local communities. Bioscience 64, 236-251.

Darwall, W.R.T. Dulvy, N.K., 1996. An evaluation of the suitability of non-specialist volunteer researchers for coral reef fish surveys. Mafia Island, Tanzania - a case study. Biol. Conserv. 78, 223-231

Derr, T., M. A., Savage, M., Schumann, M., Abrams, J., Lowe, K., 2005. Handbook one: what is multiparty monitoring? The Multiparty Monitoring Handbook Series. p. 11, Flagstaff, AZ

Devictor, V., Whittaker, R.J., Beltrame, C., 2010. Beyond scarcity: citizen science programmes as useful tools for conservation biogeography. Divers. Distrib. 16, 354-362.

Dhondt, A.A., Tessaglia, D.L., Slothower, R.L., 1998. Epidemic mycoplasmal conjunctivitis in house finches from Eastern North America. J. Wildl. Dis. 34, 265-280.

Dickinson, J.L., Zuckerberg, B., Bonter, D.N., 2010. Citizen science as an ecological research tool: challenges and benefits. Annu. Rev. Ecol. Evol. Syst. 41, 149-172.

Dickinson, J.L., Shirk, J., Bonter, D., Bonney, R., Crain, R.L., Martin, J., Phillips, T., Purcell, K. 2012. The current state of citizen science as a tool for ecological research and public engagement. Front. Ecol. Environ. 10, 291-297.

Dietz, T., Stern, P.C., 2008. Public Participation in Environmental Assessment and Decision Making. National Academy of Sciences, Washington, D.C.

Dirzo, R., Young, H.S., Galetti, M., Ceballos, G., Isaac, N.J.B., Collen, B., 2014. Defaunation in the Anthropocene. Science 345, 401-406.

Eden, S., 1996. Public participation in environmental policy: considering scientific counter-scientific and non-scientific contributions. Public Underst. Sci. 5, 183-204.

Edgar, G.J., Stuart-Smith, R.D., 2009. Ecological effects of marine protected areas on rocky reef communities-a continental-scale analysis. Mar. Ecol. Prog. Ser. 388, 51-62.

Edgar, G.J., Stuart-Smith, R.D., Cooper, A., Jacques, M., Valentine, J., 2016. New opportunities for conservation of handfishes (Family Brachionichthyidae) and other inconspic uous marine species through citizen science. Biol. Conserv. (Citizen Science Special Issue).

Ellwood, E.R., Primack, R.B., Talmadge, M.L., 2010. Effects of climate change on spring arrival of birds in Thoreau's concord from 1851-2007. Condor 112.
Ellwood, E.R., Temple, S.A., Primack, R.B., Bradley, N.L., Davis, C.C., 2013. Record-breaking early flowering in the Eastern United States. Plos One 8.

Ellwood, E.R., Dunckel, B.A., Flemons, P., Guralnick, R., Nelson, G., Newman, G., Newman, S., Paul, D., Riccardi, G., Rios, N., Seltmann, K.C., Mast, A.R., 2015. Accelerating the digitization of biodiversity research specimens through online public participation. Bioscience 65, 383-396.

Evans, C., Abrams, E., Reitsma, R., Roux, K., Salmonsen, L., Marra, P.P., 2005. The neighborhood Nestwatch program: participant outcomes of a citizen-science ecological research project. Conserv. Biol. 19.

Fernandez-Gimenez, M.E., Ballard, H.L., Sturtevant, V.E., 2008. Adaptive management and social learning in collaborative and community-based monitoring: a study of five community-based forestry organizations in the western USA. Ecol. Soc. 13

Forrester, T.D., Baker, M., Costello, R., Kays, R., Parsons, A.W., McShea, W.J., 2016. Creating advocates for mammal conservation through citizen science. Biol. Conserv. (Citizen Science Special Issue).

Fortmann, L., Ballard, H., 2011. Sciences, knowledges, and the practice of forestry. Eur. J. For. Res. 130, 467-477.

Fuccillo, K.K., Crimmins, T.M., de Rivera, C.E., Elder, T.S., 2015. Assessing accuracy in citizen science-based plant phenology monitoring. Int. J. Biometeorol. 59, 917-926.

Funder, M., Danielsen, F., Ngaga, Y., Nielsen, M.R., Poulsen, M.K., 2013. Reshaping conservation: the social dynamics of participatory monitoring in Tanzania's communitymanaged forests. Conserv. Soc. 11, 218-232.

Gardiner, M.M., Allee, L.L., Brown, P.M.J., Losey, J.E., Roy, H.E., Smyth, R.R., 2012. Lessons from lady beetles: accuracy of monitoring data from US and UK citizen-science programs. Front. Ecol. Environ. 10, 471-476.

Gellman, R., 2015. Crowdsourcing, Citizen Science, and the Law: Legal Issues Affecting Federal Agencies.

Germain, R.H., Floyd, D.W., Stehman, S.V., 2001. Public perceptions of the USDA Forest Service public participation process. Forest Policy Econ. 3, 113-124

Gray, S., Jordan, R., Crall, A., Newman, G., Hmelo-Silver, C., Huang, J., Novak, W., Mellor, D., Frensley, T., Prysby, M., Singer, A., 2016. Combining participatory modelling and citizen science to support volunteer conservation action. Biol. Conserv. (Citizen Science Special Issue).

Groffman, P.M., Stylinski, C., Nisbet, M.C., Duarte, C.M., Jordan, R., Burgin, A., Previtali, M.A., Coloso, J., 2010. Restarting the conversation: challenges at the interface between ecology and society. Front. Ecol. Environ. 8, 284-291.

Haberl, H., Winiwarter, V., Andersson, K., Ayres, R.U., Boone, C., Castillo, A., Cunfer, G., Fischer-Kowalski, M., Freudenburg, W.R., Furman, E., Kaufmann, R., Krausmann, F., Langthaler, E., Lotze-Campen, H., Mirtl, M., Redman, C.L., Reenberg, A., Wardell, A., Warr, B., Zechmeister, H., 2006. From LTER to LTSER: conceptualizing the socioeconomic dimension of long-term socioecological research. Ecol. Soc. 11.

Haller, S.F., Gerrie, J., 2007. The role of science in public policy: higher reason, or reason for hire? J. Agric. Environ. Ethics 20, 139-165.

Hart, J.K., Martinez, K., 2006. Environmental sensor networks: a revolution in the earth system science? Earth Sci. Rev. 78, 177-191.

Hemmi, A., Graham, I., 2014. Hacker science versus closed science: building environmental monitoring infrastructure. Inf. Commun. Soc. 17, 830-842.

Holmes, J., Clark, R., 2008. Enhancing the use of science in environmental policy-making and regulation. Environ. Sci. Pol. 11, 702-711.

Huntington, H.P., 2000. Using traditional ecological knowledge in science: methods and applications. Ecol. Appl. 10

Ingwell, L.L., Preisser, E.L., 2011. Using citizen science programs to identify host resistance in pest-invaded forests. Conserv. Biol. 25, 182-188.

Jetz, W., McPherson, J.M., Guralnick, R.P., 2012. Integrating biodiversity distribution knowledge: toward a global map of life. Trends Ecol. Evol. 27, 151-159.

Johnson, M.F., Hannah, C., Acton, L., Popovici, R., Karanth, K.K., Weinthal, E., 2014. Network environmentalism: citizen scientists as agents for environmental advocacy. Glob. Environ. Chang. 29, 235-245.

Jordan, R.C., Gray, S.A., Howe, D.V., Brooks, W.R., Ehrenfeld, J.G., 2011. Knowledge gain and behavioral change in citizen-science programs. Conserv. Biol. 25, 1148-1154

Jordan, R.C., Brooks, W.R., Gray, S.A., DeLisi, J.R., Berkowitz, A.R., 2013. Rising to the "broader impacts" challenge. Front. Ecol. Environ. 11, 234-235.

Kapoor, I., 2001. Towards participatory environmental management? J. Environ. Manag. $63,269-279$

Khatib, F., Cooper, S., Tyka, M.D., Xu, K., Makedon, I., Popovic, Z., Baker, D., Foldit, P., 2011. Algorithm discovery by protein folding game players. Proc. Natl. Acad. Sci. U. S. A. 108, 18949-18953.

Laidler, G.J., 2006. Inuit and scientific perspectives on the relationship between sea ice and climate change: the ideal complement? Clim. Chang. 78, 407-444.

Lane, R., Vanclay, F., Wills, J., Lucas, D., 2007. Museum outreach programs to promote community engagement in local environmental issues. Aust J. Public Adm. 66, 159-174.

Lawrence, A., 2006. 'No personal motive?' Volunteers, biodiversity, and false dichotomies of participation. Ethics Place Environ. J. Philos. Geogr. 9, 279-298.

Lewandowski, E.J., 2016. Butterfly citizen scientists in the United States increase their engagement in conservation. Biol. Conserv. (Citizen Science Special Issue).

Liebenberg, L., Steventon, J., Brahman, N., Benadie, K., Minye, J., Langwane, H., Xhukwe, Q., 2016. Smartphone icon user interface design for non-literate trackers and its implications for an inclusive citizen science. Biol. Conserv. (Citizen Science Special Issue).

Litle, K., Parrish, J.K., Dolliver, J., 2006. The coastal observation and seabird survey team citizens monitoring coastal environmental health in Alaska. Aleutian Life Forum. Alaska Sea Grant College Program, Unalaska, AK, pp. 21-38.

Long, R.J., B.T.C., 1999. The Federal Advisory Committee Act and Public Participation in Environmental Policy. Resources for the Future, Washington, DC.

Losey, J.E., Perlman, J.E., Hoebeke, E.R., 2007. Citizen scientist rediscovers rare ninespotted lady beetle, Coccinella novemnotata, in eastern North America. J. Insect Conserv. 11, 415-417. 
Mascia, M.B., Brosius, J.P., Dobson, T.A., Forbes, B.C., Horowitz, L., McKean, M.A., Turner, N.J., 2003. Conservation and the social sciences. Conserv. Biol. 17, 649-650.

McCauley, D.J., Pinsky, M.L., Palumbi, S.R., Estes, J.A., Joyce, F.H., Warner, R.R., 2015. Marine defaunation: animal loss in the global ocean. Science (347, 247-+).

McCormick, S., 2012. After the cap: risk assessment, citizen science and disaster recovery. Ecol. Soc. 17.

McDonough-MacKenzie, C., Murray, G., Primack, R., Weihrauch, D., 2016. Lessons from citizen science: assessing volunteer-collected plant phenology data with Mountain Watch. Biol. Conserv. (Citizen Science Special Issue)

McKinley, D.C., Briggs, R.D., Bartuska, A.M., 2012. When peer-reviewed publications are not enough! Delivering science for natural resource management. Forest Policy Econ. 21, 1-11.

McLain, R.J., Christensen, H.H., Shannon, M.A., 1998. When amateurs are the experts: amateur mycologists and wild mushroom politics in the Pacific Northwest, USA. Soc. Nat. Resour. 11, 615-626.

McNie, E.C., 2007. Reconciling the supply of scientific information with user demands: an analysis of the problem and review of the literature. Environ. Sci. Pol. 10, 17-38

Meentemeyer, R.K., Dorning, M.A., Vogler, J.B., Schmidt, D., Garbelotto, M., 2015. Citizen science helps predict risk of emerging infectious disease. Front. Ecol. Environ. 13, 189-194.

Middleton, J.V., 2001. The stream doctor project: community-driven stream restoration. Bioscience 51, 293-296.

Miller-Rushing, A., Primack, R., Bonney, R., 2012. The history of public participation in ecological research. Front. Ecol. Environ. 10, 285-290.

Munson, M.A., Caruana, R., Fink, D., Hochachka, W.M., Iliff, M., Rosenberg, K.V., Sheldon, D., Sullivan, B.L., Wood, C., Kelling, S., 2010. A method for measuring the relative information content of data from different monitoring protocols. Methods Ecol. Evol. 1, 263-273.

Nerbonne, J.F., Nelson, K.C., 2004. Volunteer macroinvertebrate monitoring in the United States: resource mobilization and comparative state structures. Soc. Nat. Resour. 17 817-839.

Newman, G., Graham, J., Crall, A., Laituri, M., 2011. The art and science of multi-scale citizen science support. Ecol. Inf. 6, 217-227.

Newman, G., Wiggins, A., Crall, A., Graham, E., Newman, S., Crowston, K., 2012. The future of citizen science: emerging technologies and shifting paradigms. Front. Ecol. Environ. 10, 298-304.

Newman, G., Clyde, M., McGreavy, B., Chandler, M., Haklay, M., Ballard, H., Gray, S., Mellor, D., Gallo, J., 2016. Leveraging the power of place in citizen science for effective conservation decision making. Biol. Conserv. (Citizen Science Special Issue).

Nichols, J.D., Williams, B.K., 2006. Monitoring for conservation. Trends Ecol. Evol. 21 668-673.

Overdevest, C., Huyck Orr, C., Stepenuck, K., 2004. Volunteer stream monitoring and local participation in natural resource issues. Human Ecology Review, pp. 177-185.

Parsons, J., Lukyanenko, R., Wiersma, Y., 2011. Easier citizen science is better. Nature 471 (37-37).

Pimm, S.L., Raven, P., 2000. Biodiversity - extinction by numbers. Nature 403, 843-845.

Pimm, S.L., Russell, G.J., Gittleman, J.L., Brooks, T.M., 1995. The future of biodiversity. Science 269, 347-350.

Poelen, J.H., Simons, J.D., Mungall, C.J., 2014. Global biotic interactions: an open infrastructure to share and analyze species-interaction datasets. Ecol. Inf. 24, 148-159.

Polgar, C., Gallinat, A., Primack, R.B., 2014. Drivers of leaf-out phenology and their implications for species invasions: insights from Thoreau's concord. New Phytol. 202, 106-115.

Powell, M.C., Colin, M., 2008. Meaningful citizen engagement in science and technology what would it really take? Sci. Commun. 30, 126-136.

Predmore, S.A., Stern, M.J., Mortimer, M.J., Seesholtz, D.N., 2011. Perceptions of legally mandated public involvement processes in the US Forest Service. Soc. Nat. Resour. $24,1286-1303$.

Price, C.A., Lee, H.-S., 2013. Changes in participants' scientific attitudes and epistemological beliefs during an astronomical citizen science project. J. Res. Sci. Teach. 50, 773-801.

Primack, R.B., Miller-Rushing, A.J., 2012. Uncovering, collecting, and analyzing records to investigate the ecological impacts of climate change: a template from Thoreau's concord. Bioscience 62, 170-181.

Raymond, C.M., Fazey, I., Reed, M.S., Stringer, L.C., Robinson, G.M., Evely, A.C., 2010. Integrating local and scientific knowledge for environmental management. J. Environ. Manag. 91, 1766-1777.

Regan, T., 2014. Fossil finders: prowling shores, diving in swamps. Paleo Quest Researchers Expeditions for Prehistoric Treasure Garner Them the Highest Recognition. Northern Virginia Magazine.

Ries, L., Oberhauser, K., 2015. A citizen army for science: quantifying the contributions of citizen scientists to our understanding of monarch butterfly biology. Bioscience 65, 419-430.

Robertson, D.P., Hull, R.B., 2003. Public ecology: an environmental science and policy for global society. Environ. Sci. Pol. 6, 399-410.

Rodriguez, J.P., 2002. Range contraction in declining North American bird populations. Ecol. Appl. 12, 238-248.

Rowe, G., Frewer, L.J., 2005. A typology of public engagement mechanisms. Sci. Technol. Hum. Values 30, 251-290.

Sauer, J.R., Fallon, J.E., Johnson, R., 2003. Use of North American Breeding Bird Survey data to estimate population change for bird conservation regions. J. Wildl. Manag. 67, 372-389.

Scassa, T., Chung, H., 2015. Typology of Citizen Science Projects From an Intellectual Property Perspective: Invention and Authorship Between Researchers and Participants, Washington, DC.

Scheffers, B.R., Joppa, L.N., Pimm, S.L., Laurance, W.F., 2012. What we know and don't know about Earth's missing biodiversity. Trends Ecol. Evol. 27, 501-510.
Schultz, C.A., Jedd, T., Beam, R.D., 2012. The collaborative forest landscape restoration program: a history and overview of the first projects. J. For. 110, 381-391.

Selin, S.W., Pierskalla, C., Smaldone, D., Robinson, K., 2007. Social learning and building trust through a participatory design for natural resource planning. J. For. 105, 421-425.

Shanley, P., Lopez, C., 2009. Out of the loop: why research rarely reaches policy makers and the public and what can be done. Biotropica 41, 535-544.

Shirk, J.L., Ballard, H.L., Wilderman, C.C., Phillips, T., Wiggins, A., Jordan, R., McCallie, E. Minarchek, M., Lewenstein, B.V., Krasny, M.E., Bonney, R., 2012. Public participation in scientific research: a framework for deliberate design. Ecol. Soc. 17.

Silvertown, J., 2009. A new dawn for citizen science. Trends Ecol. Evol. 24, 467-471.

Smith, B., 2014. Agency Liability Stemming From Citizen-Generated Data. The Wilson Center, Commons Lab, Washington, DC.

Snall, T., Kindvall, O., Nilsson, J., Part, T., 2011. Evaluating citizen-based presence data for bird monitoring. Biol. Conserv. 144, 804-810.

Solli, P.E., Wilson Rowe, E., Yennie Lindgren, W., 2013. Coming into the cold: Asia's Arctic interests. Polar Geogr. 36, 253-270.

Steelman, T.A., 1999. The public comment process. J. For. 97, 22-26.

Steelman, T.A., 2001. Elite and participatory policymaking: finding balance in a case of $\mathrm{Na}-$ tional Forest planning. Policy Stud. J. 29, 71-89.

Steffen, W., Grinevald, J., Crutzen, P., McNeill, J., 2011. The Anthropocene: conceptual and historical perspectives. Phil. Trans. R. Soc. A 369, 842-867.

Stepenuck, K.F., Green, L.T., 2015. Individual- and community-level impacts of volunteer environmental monitoring: a synthesis of peer-reviewed literature. Ecol. Soc. 20.

Sullivan, P.J., Acheson, J.M., Angermeier, P.L., Faast, T., Flemma, J., Jones, C.M., Knudsen, E.E., Minello, T.J., Secor, D.H., Wunderlich, R., Zanetell, B.A., 2006. Defining and implementing - best available science for fisheries and environmental science, policy, and management. Fisheries 31, 460-465.

Sullivan, B.L., Wood, C.L., Iliff, M.J., Bonney, R.E., Fink, D., Kelling, S., 2009. eBird: a citizenbased bird observation network in the biological sciences. Biol. Conserv. 142, 2282-2292.

Sullivan, B.L., Phillips, T., Dayer, A.A., Wood, C.L., Farnsworth, A., Iliff, M.J., Davies, I.J. Wiggins, A., Fink, D., Hochachka, W., Rodewald, A.D., Rosenberg, K.V., Bonney, R., Kelling, S., 2016. Using open access observational data for conservation action: a case study for birds. Biol. Conserv. (Citizen Science Special Issue).

Sultana, P., Abeyasekera, S., 2008. Effectiveness of participatory planning for community management of fisheries in Bangladesh. J. Environ. Manag. 86, 201-213.

Sunderland, T., Sunderland-Groves, J., Shanley, P., Campbell, B., 2009. Bridging the gap: how can information access and exchange between conservation biologists and field practitioners be improved for better conservation outcomes? Biotropica 41, 549-554

Theobald, E.J., Ettinger, A.K., Burgess, H.K., DeBey, L.B., Schmidt, N.R., Froehlich, H.E. Wagner, C., HilleRisLambers, J., Tewksbury, J., Harsch, M.A., Parrish, J.K., 2015. Global change and local solutions: tapping the unrealized potential of citizen science for biodiversity research. Biol. Conserv. 181, 236-244.

Thompson, J.R., Elmendorf, W.F., McDonough, M.H., Burban, L.L., 2005. Participation and conflict: lessons learned from community forestry. J. For. 103, 174-178.

Trumbull, D.J., Bonney, R., Bascom, D., Cabral, A., 2000. Thinking scientifically during participation in a citizen-science project. Sci. Educ. 84, 265-275.

Tulloch, A.I.T., Possingham, H.P., Joseph, L.N., Szabo, J., Martin, T.G., 2013. Realising the full potential of citizen science monitoring programs. Biol. Conserv. 165, 128-138.

United States Department of Agriculture, F.S., 2011. National Forest System Land Management Planning; proposed rule. In: U.F. Service (Ed.), 36 CFR Part 219. National Archives and Records Administration, Federal Register.

van Strien, A.J., van Swaay, C.A.M., Termaat, T., 2013. Opportunistic citizen science data of animal species produce reliable estimates of distribution trends if analysed with occupancy models. J. Appl. Ecol. 50, 1450-1458.

Vogel, C., Moser, S.C., Kasperson, R.E., Dabelko, G.D., 2007. Linking vulnerability, adaptation, and resilience science to practice: pathways, players, and partnerships. Glob. Environ. Chang. 17, 349-364.

Walker, D.H., 2002. Decision support, learning and rural resource management. Agric Syst. 73, 113-127.

Wallace, R.D., Bargeron, C.T., 2014. Identifying invasive species in real time: early detection and distribution mapping system (EDDMapS) and other mapping tools. In: Ziska, L.H. Dukes, J.S. (Eds.), Invasive Species and Global Climate Change. CAB International, p. 219

Wallowa County Community Planning Process Group, 2005. Upper Joseph Creek Watershed Assessment. Wallowa Resources, Wallowa, Oregon.

Wals, A.E.J., Brody, M., Dillon, J., Stevenson, R.B., 2014. Science education convergence between science and environmental education. Science 344, 583-584.

Wesselink, A., Paavola, J., Fritsch, O., Renn, O., 2011. Rationales for public participation in environmental policy and governance: practitioners' perspectives. Environ. Plan. A 43, 2688-2704.

Wiersma, Y.F., 2010. Birding 2.0: citizen science and effective monitoring in the web 2.0 world. Avian Conserv. Ecol. 5, 9

Winter, G.J., Vogt, C., Fried, J.S., 2002. Fuel treatments at the wildland-urban interface common concerns in diverse regions. J. For. 100, 15-21.

Yaffee, S.L., Wondolleck, J.M., 1995. Building knowledge pools and relationships. J. For. 93, 68

Yamamoto, Y.T., 2012. Values, objectivity and credibility of scientists in a contentious natural resource debate. Public Underst. Sci. 21, 101-125.

Zapponi, L., Cini, A., Bardiani, M., Hardersen, S., Maura, M., Maurizi, E., Redolfi De Zan, L., Audisio, P., Bologna, M.A., Carpaneto, G.M., Roversi, P.F., Sabbatini Peverieri, G., Mason, F., Campanaro, A., 2016. Citizen science data as an efficient tool for mapping protected saproxylic beetles. Biol. Conserv. (Citizen Science Special Issue).

Zerbe, F., Wilderman, C., 2010. Monitoring impacts of new gas-drilling technologies. The Volunteer Monitor.

Zerger, A., Rossel, R.A.V., Swain, D.L., Wark, T., Handcock, R.N., Doerr, V.A.J., Bishop-Hurley, G.J., Doerr, E.D., Gibbons, P.G., Lobsey, C., 2010. Environmental sensor networks for vegetation, animal and soil sciences. Int. J. Appl. Earth Obs. Geoinf. 12, 303-316. 